\title{
Halina Wierzyńska - o podróżach wojennych i emigracyjnych
}

\author{
(opracowanie edytorskie Beata Dorosz)
}

Sztuka Edycji 1/2017

ISSN 2084-7963 (print)

ISSN 2391-7903 (online)

s. 193-221
Halina Wierzyńska, żona Kazimierza, udzieliła w Nowym Jorku pod koniec lat siedemdziesiątych ubiegłego wieku obszernego wywiadu Jerzemu Tepie na temat wojennego exodusu z Polski we wrześniu 1939 roku i wędrówki emigracyjnej; do podjęcia wyzwania związanego z przygotowaniem go do druku skłoniła mnie tematyka prezentowanego zeszytu „Sztuki Edycji”, czyli „Podróżopisarstwo”. Nagranie stanowi część realizowanego w latach 1977-1983 w Stanach Zjednoczonych projektu pt. Oral History and History of Ideas, wpisującego się w popularny wówczas w Ameryce nurt badań nad mniejszościami etnicznymi. W Polskim Instytucie Naukowym w Ameryce (z siedzibą w Nowym Jorku) przeprowadzono wywiady biograficzne z artystami, politykami, naukowcami, zwłaszcza historykami, badaczami dziejów Polonii, którzy po 1939 roku wyemigrowali z Polski i ostatecznie osiedli w USA - wśród rozmówców Jerzego Tepy i Wojciecha Wańtuły znaleźli się m.in. Feliks Gross, Wacław Jędrzejewicz, Jan Karski, Stefan Korboński, ale też Adam Panufnik, Leopold Stokowski, Halina Rodzińska, Halina Wittlinowa i Halina Wierzyńska. Tematem rozmów były przede wszystkim okoliczności wyjazdu z kraju oraz wrażenia i doświadczenia z zetknięcia się z Ameryką i adaptacji do nowych warunków życia; wywiadom tym przyświecał przede wszystkim cel dokumentacyjny: zarejestrowanie (przy pomocy dostępnych wówczas możliwości technologicznych) istotnych dla historii polskiego wychodźstwa relacji świadków i uczestników wydarzeń ${ }^{1}$. Tu niewątpliwie pierwszoplanowym bohaterem jest Kazimierz

Nie sposób jednak wykluczyć, że niektóre z tych nagrań-wywiadów mogły być w późniejszym okresie wykorzystywane przy różnych okazjach, np. jubileuszowych, nie są mi wszakże znane żadne dane na ten temat. 
Wierzyński, ale jego wojenna i powojenna peregrynacja widziana jest oczami jego żony Haliny (z Pfefferów, $1^{\circ}$ voto Sztompkowej; 1903-1980), przed wojną pracującej m.in. jako sekretarka tygodnika „Wiadomości Literackie” i zajmującej się przekładami z języka francuskiego. Jej relacja znajduje swego rodzaju potwierdzenie i dopełnienie w wychodźczych doświadczeniach jej interlokutora, Jerzego Tepy (1908-1992), w latach trzydziestych pracownika rozgłośni lwowskiej Polskiego Radia, autora głośnej sztuki dramatycznej Fräulein Doktor (prapremiera odbyła się we Lwowie w 1933 roku), a po wojnie w Stanach Zjednoczonych przez wiele lat zatrudnionego w waszyngtońskim radiu Voice of America (Głos Ameryki). Kasety magnetofonowe z tymi rozmowami wchodzą w skład Kolekcji Nagrań Dźwiękowych w archiwum PIN².

Zamysł opublikowania tekstu, którego pierwotną formą jest nagranie dźwiękowe, niesie w sobie jednak wiele trudności i dylematów. W wielu archiwach, bibliotekach i muzeach przechowywane są różnego typu nagrania dźwiękowe (na taśmach studyjnych, taśmach i kasetach magnetofonowych, płytach winylowych i CD), zawierające np. zapisy programów artystycznych, wieczorów autorskich, wywiady z wybitnymi postaciami życia kulturalno-literackiego czy naukowego itp. W dobie podejmowanej dość powszechnie digitalizacji rozmaitych zasobów archiwalnych nie jest jednak możliwe opracowanie wszystkich tych nagrań tak, by mogły być dostępne w postaci cyfrowej (np. przez internet) jako dokumenty dźwiękowe; dla wielu (a wolno przypuszczać, że dla większości) najprostszym sposobem zapoznania się z niesionymi przez nie treściami wydaje się tradycyjny druk, czyli odsłuchanie nagrania z nośnika dźwiękowego i zapisanie go w druku3 . Badacze literatury, a w tym wypadku edytorzy (dodajmy: dość specyficznego rodzaju), nie mają jednak do dyspozycji żadnych teoretycznych założeń czy metodologicznych wskazówek, które dotyczyłyby „przekładu” tekstu nagranego na wersję przeznaczoną do druku.

Zasadniczym dylematem związanym z takim wyzwaniem jest podjęcie decyzji, czy celem edycji odsłuchanego tekstu będzie dążenie do przedstawienia jak najbliższej jego realizacji fonicznej, czy też ustalenie takiej formy zapisu, która pozwoliłaby na jak najlepsze oddanie zawartych w nagraniu treści.

Wariant pierwszy $\mathrm{w}$ istocie z góry skazany jest na niepowodzenie, a badaniu formy musi bezwzględnie towarzyszyć kontakt z nagraniem dźwiękowym. Nie da się wszak w żaden sposób zapisać timbrẻ u głosu, emocji towarzyszących np. wywiadowi, temperamentu rozmówców itd.; tylko w formie dźwiękowej pozostaną więc pauzy czy zawieszenia głosu wynikające z namysłu, zająknienia, będące efektem swego rodzaju antycypacji myślowej, tj. inaczej zaplanowanej koncepcji wypowiedzi, zmienianej w trakcie rozmowy, widoczne m.in. w powtórzeniach bądź błędach składniowych.

Wydaje się, że drukowany zapis nagrań dźwiękowych powinien skupić się na referowaniu treści - bo to ona może mieć istotne znaczenie np. dla historyka literatury czy biografa. Edytor tego specyficznego tekstu staje się więc poniekąd jego „współautorem”, delikatnie „podredagowując” jego postać przeznaczoną do druku (przez usunięcie kolokwializmów, błędów, zająknięć i powtórzeń itp.). Działania te mają szczególną wagę, gdy

2 PIN, kolekcja 019, Oral History; wywiad H. Wierzyńskiej - taśmy: O2 / 129-131. Kopia nagrania znajduje się w Muzeum Literatury im. A. Mickiewicza w Warszawie, przywieziona z Nowego Jorku w 1982 roku przez Stanisława Wierzyńskiego, bratanka Kazimierza.

Stosunkowo prosta była rejestracja w druku audycji Radia Wolna Europa, na które składały się felietony radiowe pisarzy, będące wszakże gotowymi tekstami literackimi (zob. V. Wejs-Milewska, Radio Wolna Europa na emigracyjnych szlakach pisarzy, Kraków 2007); udostępnienie ich w tej formie w nieporównywalny sposób zwiększa ich dostępność dla badaczy niż archiwalne taśmy RWE zachowane w Archiwum Dokumentacji Mechanicznej w Warszawie. 
niemożliwa jest np. autoryzacja wywiadów zarówno pod względem merytorycznym, jak i stylistycznym ${ }^{4}$. Trzeba też pamiętać, że wszystkie edycje mają w pewnym sensie charakter subiektywny - działania edytora, nawet podyktowane jego najlepszą wolą i najwyższymi umiejętnościami, są jednak obcą ingerencją w tekst pochodzący od innego autora; w wypadku transponowania nagrania na formę pisemną ingerencje te bywają zapewne częstsze i bardziej konieczne, ale też w konfrontacji dźwięku z drukiem stają się bardziej zauważalne.

Nie mniej istotna wydaje się też „gra wyobraźni” czytelnika, który jest odbiorcą tak przygotowanego przez edytora tekstu. Świadomy jego pierwotnej dźwiękowej postaci i zdając sobie sprawę, że słowom towarzyszyły w rozmowie i mimika, i gestykulacja, i swada rozmówców, wchodzi z nimi w pewnego rodzaju relację, a podejmując interpretację treści, stara się też dociec wszystkich tych niuansów, których nie udało się oddać w drukus.

Prezentowana tu po raz pierwszy w druku wypowiedź Haliny Wierzyńskiej, choć nawiązuje do znanych faktów z życia męża-poety, przynosi jednak wiele nowych szczegółów, istotnych dla badaczy jego biografii, nadto pochodzących z tzw. pierwszej ręki. Wydaje się, że emocje, które towarzyszyły Wierzyńskim na etapie wojennego exodusu, były we wspomnieniach Haliny wciąż żywe, o tych dramatycznych wydarzeniach mówi bowiem ciekawie i z autentycznym zaangażowaniem, aczkolwiek zapewne właśnie rodzaj emocjonalnego napięcia sprawił, że jej wypowiedź jest miejscami nieco chaotyczna, powtarzająca pewne wątki, a niektóre informacje są nie do końca dokładne; dowodzi to dramatyzmu wspominanych sytuacji, które w pamięci świadków utrwaliły się ze sprzecznymi niekiedy szczegółami. Wyraźny jest zresztą ton dość swobodnie płynącej gawędy wspomnieniowej, aczkolwiek zapewne wcześniej zaplanowanej, na co wskazywałyby niektóre wypowiadane przez Wierzyńską (w specjalny sposób) frazy oraz sporadyczne wspomaganie się przez nią notatkami, gdy chce jak najdokładniej przytoczyć albo tytuły wierszy Kazimierza, albo zacytować fragment jego wypowiedzi; wydaje się też, że nagranie (którego dokładna data nie jest znana) odbyło się podczas jednej sesji, niewątpliwie męczącej dla obojga rozmówców, jako że zachowany materiał dźwiękowy trwa blisko dwie i pół godziny (problemem nie do rozwiązania w odtworzeniu logicznego ciągu całej rozmowy jest znaczne uszkodzenie nagrania w dwóch miejscach na taśmie - zapewne w trakcie kopiowania dla innych potrzeb). Można by ten wywiad uznać za „pośmiertny” debiut Haliny jako autorki o indywidualnym talencie narracyjnym, znanej tylko z pracy przekładowej ${ }^{6}$. Udział Jerzego Tepy w tej rozmowie sprowadzał się raczej do niewielkich wtrąceń, stąd jego wypowiedzi, często jednoczesne z wypowiedziami interlokutorki, brzmią jak niedokończone.

${ }^{4}$ Poza tymi rozważaniami sytuują się tzw. wywiady-rzeki, starannie przygotowywane do wydania, choć ich prymarną postacią była rozmowa zarejestrowana na taśmie; najbardziej znanym dziełem literackim w tej kategorii jest Mój wiek Aleksandra Wata, z którym rozmowy przeprowadził Czesław Miłosz, a do druku przygotowała je Lidia Ciołkoszowa (Londyn 1977); podobnie seria wywiadów Renaty Gorczyńskiej (pseud. Ewa Czarnecka) z Miłoszem na temat jego twórczości Podróżny świata (New York 1983). Szczególnym zabiegom redakcyjnym i autoryzacyjnym podlegały też materiały zbierane przez Teresę Torańską do jej słynnej serii książek-rozmów; zwłaszcza w wypadku wywiadów z byłymi PRL-owskimi decydentami (Oni, Warszawa 1985, drugi obieg, liczne wznowienia), oceniającymi własne dokonania, rozmówczyni poddana była ich autoryzacyjnej presji.

${ }^{5}$ Za zwrócenie uwagi na podwojenie układu komunikacyjnego (w tym wypadku: z jednej strony Wierzyńska-Tepa, z drugiej uczestnicy wywiadu a odbiorca drukowanego tekstu) dziękuję Pani dr Magdalenie Kowalskiej, redaktorce prezentowanego zeszytu „Sztuki Edycji”.

${ }^{6}$ Tłumaczyła z języka francuskiego powieść biograficzną Guy de Pourtalèsa Życie Liszta, drukowaną w odcinkach w 1938 roku w "Gazecie Polskiej” (wyd. osob. Warszawa 1948). 
W zapisie rozmowy zastosowano tradycyjną pisownię dat i godzin przy użyciu cyfry (1 września zamiast pierwszego września, 5 rano, a nie piąta rano); nieoczywistą do końca pisownię obcych nazwisk oznaczono jako [?]; znak trzykropka ... oznacza z jednej strony dłuższą niekiedy chwilę namysłu, z drugiej - ma za zadanie odzwierciedlić nawiązywanie wątku przez rozmówcę niejako w pół słowa poprzednika; tekst poddano drobnym korektom stylistycznym, usuwając np. inne zamysły realizacyjne (np. do przyjemnej strony tego należato... należaty spotkania, albo No więc, Kazimierz..., potem wynajęliśmy); usunięto bardzo drobne fragmenty tekstu (np. potakiwania Tepy służące jedynie podtrzymaniu wątku, tak, tak, albo tak, rozumiem lub $u$ hm...) oraz uwagi odnoszące się bezpośrednio do procesu nagrywania rozmowy (np. tu będziemy musieli wycią́ kichnięcie).

Zdając sobie sprawę, że nie wszystkie przyjęte tu rozwiązania zyskałyby ogólną aprobatę, traktuję ogłoszenie tego wywiadu w druku jako zaproszenie środowiska edytorów do dyskusji na temat: jak edytować teksty odsłuchane z nagrań dźwiękowych - wszelkie uwagi teoretyczne i sugestie metodologiczne na kanwie podjętej przeze mnie próby przybliżą zapewne wypracowanie podstawowych zasad takich publikacji.

[cz. I]

Jerzy Tepa: Jesteśmy w studio Polskiego Instytutu Naukowego w Nowym Jorku i rozmawiamy w tej chwili z Panią Haliną Wierzyńską, wdową po jednym z największych poetów, jakich Polska posiadała. Poety trzech epok, a więc tzw. międzywojennej, wojennej i powojennej, czy (jak inaczej wolimy nazwać) emigracyjnej. Proszę Pani, przejdźmy od razu do istoty rzeczy. Pierwsze pytanie: w jakich warunkach i gdzie zastał Państwa Obojga wybuch drugiej wojny światowej?

Halina Wierzyńska: Wybuch wojny zastał nas w Warszawie, w naszym niewykończonym prawie jeszcze mieszkaniu, bo pobraliśmy się dopiero w grudniu $38 \mathrm{roku}^{7}$, przy ulicy Belwederskiej 32 naprzeciw parku Łazienkowskiego. Okna wychodziły na park, na jego dziką część, która była bardzo piękna właśnie w jesieni, była pełna młodych jesionów, żółtych, prześwietlonych, bardzo pięknych... Byliśmy też po wspaniałych wakacjach. Pełni polskiego pejzażu. Jakby w przeczuciu, że długo Polski nie zobaczymy, a mój mąż nigdy, pojechaliśmy w dwa krańce Polski, najpierw nad morze, do państwa Urbanowiczów ${ }^{8}$, do Juraty, a potem ważniejszą część tych wakacji spędziliśmy w Sienieżycach na Litwie u Balińskich, u Jana Jundziłła ${ }^{9}$, brata Stanisława Balińskiego. To był bardzo piękny kraj, właściwie jak wyjęty z Pana Tadeusza, pełen wspomnień historycznych, Ludwiki Śniadeckiej, Odyńca i samego Mickiewicza, kraj pełen tajemniczości, bardzo malowniczy. Tak wyglądał jak zrobiony przez jakiegoś genialnego ogrodnika, jakieś kępy drzew wśród pól, i te Mickiewiczowskie białe gryki i tak dalej...,

Ślub Haliny i Kazimierza Wierzyńskich odbył się 18 grudnia 1938 roku.

${ }^{8}$ Stefan Urbanowicz (1891-1940), adwokat, obrońca w procesie brzeskim, działacz środowiska prawniczego, i Aniela z Reicherów (1899-1988), działaczka społeczno-polityczna; po wojnie m.in. założycielka warszawskiego Klubu Inteligencji Katolickiej.

9 Jan Baliński-Jundziłł herbu Jastrzębiec (1899-1974), w czasie wojny i po wojnie na emigracji; w 1940 m.in. współzałożyciel Ogniska Polskiego w Londynie. 
wszystko tam było autentyczne. Jeździliśmy czasami na spacer o księżycu i jechało się przez jakieś srebrne morze. W Sienieżycach była droga, która prowadziła przez pola do lasu, gdzie podobno jeszcze chłopi w naszych czasach chodzili na dziady, na cmentarze widziałam tam krzyże obwieszone szmatami lnianymi i dotąd nie wiem, jakiemu to użytkowi służyło.

JT: Prawdopodobnie jakiś regionalny zwyczaj, który przetrwał może nawet od czasów pogańskich.

HW: Tak, jakieś pogańskie rytualne sprawy. Żyliśmy w przeczuciu wojny co najmniej od wiosny 39 roku, a ja właściwie od przemówienia Becka o honorze z 5 marca $^{10}$; to mi się wydawało tak straszliwie smutne przemówienie. Odpędzaliśmy wszyscy myśli o najstraszniejszym, mianowicie o przewadze Niemców i naszej bezradności, bezsile, wierząc, że może powtórzy się cud nad Wisłą. Dzień 25 sierpnia to była data podpisania układu z Anglią, przyniósł trochę nadziei, ale niestety tylko na pięć-sześć dni.

JT: Państwo byliście wtedy jeszcze na wakacjach, prawda? Czy już w Warszawie?

\section{Rano 1 września usłyszeliśmy detonacje}

HW: 25 sierpnia już byliśmy w Warszawie. Rano 1 września usłyszeliśmy detonacje. Myśleliśmy, że to są przygotowania przeciwlotnicze, bo ciągle takie ćwiczenia się uprawiało. $\mathrm{O} 9$ rano zadzwonił brat Kazimierza, Hieronim ${ }^{11}$, dziennikarz, który powiedział, że Niemcy bombardowali w Warszawie i w innych miastach Polski. Zaczęła się więc wojna właściwie bez wypowiedzenia jej. Zaskoczeni i oszołomieni, czekaliśmy. Niemcy przylatywali regularnie, pracowali jak w biurze, od 5 rano do 5 po południu, potem następował spokój. Na sygnały alarmu schodziliśmy do sieni, bo nasz schron nie był jeszcze wykończony, i tam oczywiście odbywały się różne sceny na tych meetingach lokatorskich, ale do przyjemnej strony tego należały spotkania z Dorą Kalinówną ${ }^{12}$, która była naszą sąsiadką.

JT: Ale histeria już zaczęła panować wtedy, zdaje się... U ludzi już wojna zaczęła... [mówi niemal jednocześnie z $H W$ ]

HW: Tak, ponieważ wszyscy oczekiwali wojny gazowej, więc był tam taki pan, który nagle zaczął krzyczeć: „Czuję zapach musztardy!” i uciekł.

JT: A Państwo schodziliście zawsze z maskami na dół?

${ }^{10}$ Tu Wierzyńska pomyliła się - ówczesny minister spraw zagranicznych Józef Beck (1894-1944) odpowiedział 5 maja 1939 roku w Sejmie RP na mowę kanclerza Rzeszy Adolfa Hitlera z 28 kwietnia 1939 roku; analizę sytuacji politycznej zakończył stwierdzeniem: „Pokój jest rzeczą cenna i pożądaną. Nasza generacja, skrwawiona w wojnach, na pewno na pokój zasługuje. Ale pokój, jak prawie wszystkie sprawy tego świata, ma swoją cenę, wysoką, ale wymierną. My w Polsce nie znamy pojęcia pokoju za wszelką cenę. Jest tylko jedna rzecz w życiu ludzi, narodów i państw, która jest bezcenną. Tą rzeczą jest honor".

${ }^{1}$ Hieronim Wierzyński (1884-1943), publicysta, redaktor, działacz społeczny; w okresie międzywojennym związany z prasą endecką; przez wiele lat prezes Klubu Sprawozdawców Parlamentarnych oraz wiceprezes Syndykatu Dziennikarzy (później Związku Dziennikarzy RP); w czasie okupacji niemieckiej pracował w Radzie Głównej Opiekuńczej, współpracował z prasą podziemną; aresztowany w 1942 roku, został wywieziony do obozu na Majdanku, gdzie zginął.

12 Dora Kalinówna (1905-1986), przedwojenna aktorka filmowa i kabaretowa, pieśniarka rewiowa; od wybuchu drugiej wojny światowej na emigracji, występowała z recitalami w Nowym Jorku (tu także związana była z Polskim Teatrem Artystów), Ameryce Łacińskiej i Izraelu; zmarła w Rio de Janeiro. 
HW: Zawsze z maskami, bo zdawało się, będzie ta wojna miała taki charakter. Wtedy Kazimierz, już przed wojną i na początku wojny, napisał dwa wiersze, z których jeden Święty Boże jest jeszcze właściwie bardzo wojenny, mimo że napisany 30 sierpnia, a drugi Zstap, duchu mocy z 5 września ${ }^{13}$.

JT: I te wiersze oczywiście się ocaliły. Ale jak z resztą, jakeście Państwo wyjeżdżali? Ale przejdźmy może do samej decyzji wyjazdu.

HW: Tak, te wiersze ocalały, bo były drukowane w „Gazecie Polskiej”. Tego właśnie dnia, 5 września, zadzwonił do nas Matuszewski ${ }^{14}$, z którym Kazimierz się przyjaźnił, i powiedział, że powinniśmy wyjechać z Warszawy, dlatego że Niemcy są już pod Ciechanowem. Myśmy jednak zdecydowali się zostać. I 6 września zaczęliśmy dzwonić do znajomych, żeby się dowiedzieć, co oni robią. Nie było już odpowiedzi, telefony były martwe.

JT: Już popłoch się zaczął i Warszawa zaczęła pustoszeć.

HW: Tak, oni już wyjechali.

JT: I zdecydowaliście Państwo wtedy wyjechać, tak?

HW: Więc nam się zrobiło trochę głupio i zastanawialiśmy się, czy dobrze zrobiliśmy, ale taka była decyzja i siedzieliśmy.

JT: A jakie Państwo mieliście środki lokomocji?

HW: W tym momencie żadnych. Ale po południu zadzwonił do nas Aleksander Heiman, senator, mąż pierwszej Wierzyńskiej ${ }^{15}$, mojej poprzedniczki, i powiedział, że oni wyjeżdżają wieczorem, ale mają jedno auto puste z fabryki, które moglibyśmy my wziąć. No więc to było już za silne jak na naszą już wtedy słabą wolę zostania i spakowaliśmy się co prędzej, w najlżejsze walizki, zabrałam tylko rzeczy nowe, bo myśleliśmy, że może będzie trzeba te walizki nosić. Ja pojechałam po moją siostrę ${ }^{16}$ i o 9 godzinie opuściliśmy Warszawę, kierując się...

JT: A co Państwo zostawiliście, przepraszam, że przerywam...

HW: Wszystko!

JT: ...jak chodzi o twórczość Kazimierza. Czy wziął troszkę swoich wierszy?

3 Pierwodruk odpowiednio: „Gazeta Polska” 1939, nr 241 i 248

${ }^{14}$ Ignacy Matuszewski (1981-1946), polityk, publicysta; zwolennik Józefa Piłsudskiego, po przewrocie majowym 1926 roku był jednym z czołowych reprezentantów prawicy w obozie rządzącym; w latach 1929-1931 minister skarbu, a w 1932-1936 redaktor naczelny „Gazety Polskiej”. Od 1939 roku na emigracji, w 1941 roku osiadł w Stanach Zjednoczonych; przeciwnik polityki wschodniej gen. Władysława Sikorskiego; w 1943 roku współzałożyciel Instytutu J. Piłsudskiego w Ameryce. O przyjaźni z nim wspominał poeta. Zob. K. Wierzyński, Pamiętnik poety, oprac. P. Kądziela, Warszawa 1991.

${ }_{15}$ Pierwszą żoną Wierzyńskiego od 1923 roku była aktorka, Bronisława Koyałłowicz (ur. 1890 lub 1892-zm. 1943 w Treblince); po rozwodzie, w 1933 roku, poślubiła Aleksandra Heiman-Jareckiego (1886-1966), przemysłowca, prezesa Związku Przemysłu Włókienniczego w Polsce, później senatora; po wojnie przebywał na emigracji w Australii.

${ }^{16}$ Janina z Pfefferów, późniejsza Pejczowa; po wojnie mieszkała w Warszawie. 
HW: A, o twórczość! Nic! Nic, bo miał ostatnio już zebrane wiersze w tom...

JT: ...który miał być wydany u Mortkowicza... ${ }^{17}$

HW: ...i rękopis złożył u Mortkowicza, i to było na Starym Mieście w drukarni Mortkowicza...

JT: ...i to nie ocalało do dziś dnia...

HW: Ocalało z tego parę wierszy, które potem przyjaciele - odpisywane z różnych pism, bo te wiersze były drukowane, to były wiersze $\mathrm{z}$ Prowansji $\mathrm{i}^{18}-$ nam przysyłali do Ameryki.

JT: I zdaje się, Pani mi mówiła przedtem, że część była w Róży wiatrów, prawda? To znaczy tylko część ocalała, ale Kazimierz z sobą jednej kartki nie wziął, tak?

HW: Nic, nic. Ja go się spytałam, czy brać ten rękopis, on odpowiedział: nie, przecież jest złożony u Mortkowicza.

W Zamościu sytuacja się okazała dosyć beznadziejna, bo przede wszystkim straciliśmy auto
JT: No i jakeście Państwo wyjechali? Wieczorem, oczywiście, tego samego wieczoru?

HW: Myśmy w ogóle jechali nocą, bo drogi nie były tak szalenie zaludnione.

JT: Państwo tylko dwoje-ście byli w samochodzie, tak? I szofer, czy jeszcze ktoś był?

HW: Nie, i moja siostra. Nad ranem byliśmy blisko Lublina, bo nie dojechaliśmy do Lublina, dlatego że nam powiedzieli, że Lublin jest bombardowany. Może wtedy zginął Czechowicz $^{19}$, na przykład?

JT: Tak. I wtedy, ja pamiętam, Kurów się palił cały na drodze i właściwie droga była nie do przebycia, jak chodzi o dym, i tak dalej.

HW: Tak, więc ludzie po drodze nam odradzili ten kierunek i myśmy pojechali na południowy wschód, do Zamościa. W Zamościu sytuacja się okazała dosyć beznadziejna, bo przede wszystkim straciliśmy auto. Szofer, który się zorientował, co się dzieje, postanowił wrócić do rodziny do Warszawy. Auto potem kto inny odwiózł Heimanowi do Rumunii, ale już...

JT: ...bez Państwa...

HW: ...żadne z nas nie prowadziło, więc bez nas.

Rękopis zbioru wierszy Noc prowansalska, złożony w wydawnictwie Jakuba Mortkowicza, uległ zniszczeniu; pojedyncze utwory weszły później do tomów Róża wiatrów (Nowy Jork 1942) i Korzec maku (Londyn 1951).

${ }^{18}$ Wierzyński spędził we Francji rok - od października 1937 do października 1938 roku; częściowo towarzyszyła mu Halina, oczekując na unieważnienie małżeństwa z pianistą, Henrykiem Sztompką.

${ }^{19}$ Poeta Józef Czechowicz (1903-1939) zginął 9 września 1939 roku w czasie bombardowania Lublina. 
JT: No, jak Państwo się wydostaliście z Zamościa?

HW: Przypadkiem. Kazimierz okazywał niesłychaną siłę charakteru, spokój i energię.

JT: Znaczy, nie był nerwowy zupełnie...

HW: Zupełnie nie był nerwowy, co było przeciwne jego naturze.

JT: No, w pewnych momentach życia człowiek właściwie się opanowuje.

HW: Więc właśnie jest inny, tak...

JT: ...chłodny, tak...

HW: Podszedł do niego po prostu jakiś pan i powiedział: „Pan na pewno tutaj zna wszystkich, niech Pan mi zdobędzie benzynę, a ja Panu dam trzy miejsca w samochodzie".

JT: No, to cudowna okazja!

HW: Cudowna okazja! I tak się stało. Kazimierz gdzieś tam znalazł jakieś wysoko postawione osoby, które mu tę benzynę dały, i wyjechaliśmy wtedy w kierunku na Lwów, gdzie znowu jeszcze z jakimś cieniem optymizmu, że tam będzie „Gazeta Polska”.

JT: Czy dojechaliście Państwo do Lwowa?

HW: Dojechaliśmy do Lwowa! I wtedy zamieszkaliśmy u tego młodego poety, u jego żony, on się (zdaje się) nazywał Andrzej Kruczkowski ${ }^{20}$. I mieszkaliśmy przez kilka dni, oczywiście chodziliśmy na wszystkie takie spotkania uchodźców do Żorża ${ }^{21}$.

JT: Rozumiem doskonale, oczywiście. Wtedy tylko grupki się tworzyły i starały się myśleć, co będzie jutro.

HW: Tak. I tam chyba Kazimierz spotkał Hemara, który był u swojej matki (która mieszkała we Lwowie) i miał auto. Z nim byli także Norblinowie, Stefan i jego żona Lena Żelichowska, aktorka ${ }^{22}$. Więc Hemar się wahał, nie chciał zostawić matki samej, ale jakoś (czy ja wiem?) też czas zrobił swoje i uległ. I wyjechaliśmy ze Lwowa, mnie się wydaje, że to było 12 [września]. Pojechaliśmy w kierunku granicy rumuńskiej, do majątku państwa Jaruzelskich (nie wiem, czy ten generał Jaruzelski to był z nich?).

${ }^{20}$ Andrzej Zdzisław Kruczkowski (zm. 2006), wchodził w skład redakcji „Sygnałów”, lewicowego miesięcznika społeczno-kulturalnego wydawanego we Lwowie w latach 1933-1939; po wojnie pracownik dyplomacji PRL oraz urzędnik Ministerstwa Handlu Zagranicznego.

${ }^{21}$ Mowa o reprezentacyjnym Iwowskim Hotelu George.

22 Stefan Norblin (1892-1952), artysta plastyk, malarz, ilustrator; Lena (Helena) Żelichowska (1910-1958), aktorka filmowa, rewiowa i teatralna. W czasie wojny przebywali w Persji, potem w Indiach, w 1946 roku osiedlili się w San Francisco. 
JT: Nie wiem, nie znam tej rodziny. Prawdopodobnie krewny, bo nazwisko jest niezwykłe, więc...?

HW: Niezwykłe, tak. Majątek (zdaje się) nazywał się Kniazie ${ }^{23}$. Już we dworze nie było miejsca, tam mieszkali jacyśs wysocy oficerowie, między innymi wśród nich był Wyżeł-Ścieżyński ${ }^{24}$. A myśmy zamieszkali u mleczarza, co zresztą wyszło nam na dobre, bo nie mieliśmy tych obowiązków towarzyskich, a poza tym to było pięknie położone, w sadzie, tak było wtedy cudownie, że właściwie to były dni błogostanu. Już to był kraniec, prawda? Dobiliśmy do muru. Już nie można było nic robić więcej.

JT: Ale jednak był czas i miejsce na euforię, prawda?

HW: Był czas. To strasznie dziwne, bo to się działo zresztą w ciągu tej podróży, potem to samo było w Rumunii, jakeśmy mieszkali u Rumunów, że był jakiś taki spokój i szczęście, i właściwie jednocześnie koszmar, bo dręczyło nas wszystko to.

JT: Tak, ale kraj był neutralny, więc nie było bezpośredniego niebezpieczeństwa.

HW: Ziemia była neutralna. No i tam byliśmy kilka dni. Ponieważ to było niedaleko szosy, więc widzieliśmy, jak auta jechały na wschód, z uchodźcami, i nagle pewnego dnia zobaczyliśmy, że jadą na zachód, więc zatrzymaliśmy ich, spytaliśmy, oni powiedzielito było 17 [września]: „Bolszewicy przeszli granicę i zajmują polskie ziemie”. Więc myśmy... nie wiem, ile tego wahania było, pół dnia, czy coś takiego, czy dzień...

JT: No, zdecydowaliście się Państwo jednak opuścić kraj, w którym było dwóch okupantów, naturalnie.

HW: Zdecydowaliśmy się jechać na granicę, tak. Mnie się wydaje, że przejechaliśmy ją w Kutach. Hemar, który robił notatki, mówi, że w Śniatyniu, więc nie wiem, może on miał rację?25 Wiem, że po drugiej stronie granicy była miejscowość Storożyniec, więc może to by na mapie można było odszukać, i w Storożyńcu przyjęli nas już jak uchodźców. Dwór się bardzo pięknie zachował, bo służba nam wyniosła ciepłe mleko i bułki. I jechaliśmy dalej. Ludzie zachowywali się różnie. Stali na drogach, patrzyli na nas, niektórzy płakali, niektórzy dawali nam jeść za darmo, inni wyrzucali po prostu, wypraszali bardzo brutalnie, jakeśmy im pokazywali nasze polskie złotówki. No, zaopiekowała się nami też policja, zapisali sobie numer auta i skierowali nas na miejscowość Solka, gdzie

${ }^{23}$ W istocie nazwa brzmiała Kniaże; majątek (pow. Śniatyń, woj. stanisławowskie, nad rzeką Czeremosz) należał do Józefa i Izabeli Jaruzelskich (dziadków późniejszego aktora Zbigniewa Cybulskiego); gen. Wojciech Jaruzelski był wnukiem Wojciecha Jaruzelskiego, brata Józefa, zamieszkałego w Kurowie na Podlasiu.

${ }^{24}$ Mieczysław Wyżeł-Ścieżyński (1895-1956), pułkownik dyplomowany piechoty Wojska Polskiego, w 1930 roku przeniesiony w stan spoczynku, był dyrektorem naczelnym Agencji Prasowej „Iskra”.

${ }^{25}$ Wyjazd ze Lwowa Hemara, Norblinów i Wierzyńskich nastąpił 10 września, a granicę przekroczono w Śniatyniu w nocy z 17 na 18 września; relację opartą na dzienniku Hemara zawiera książka Ja, kabareciarz. Marian Hemar od Lwowa do Londynu (oprac. A. Mieszkowska, Warszawa 2006, s. 80-82). Przeżyciom tym Hemar dał poetycki wyraz w wierszu Kazimierzowi Wierzyńskiemu (z tomu Im dalej w las, Londyn 1963): „Wciąż jeszcze przed oczami mam wieczór śniatyński. // Wciąż przede mną graniczny most w mroku majaczy. // Koło mnie, w samochodzie, poeta Wierzyński // Z twarzą w dłoniach. Wciąż jeszcze nie wiem, co to znaczy?". Do zawodności pamięci nawiązywał list Wierzyńskiej do Hemara z 3 września 1969 roku, w którym prosiła o przypomnienie szczegółów z ich wspólnej podróży, pisząc: „Papiery rozpadły się po mieszkaniach spalonych i archiwach zagubionych czy niedostępnych, a wspomnienia ulatniają się z coraz bardziej zawodnych głów ludzkich" (Ja, kabareciarz, s. 83). 
mieliśmy dostać inne instrukcje. Myśmy próbowali im uciekać, oczywiście, ale oni byli bardzo dobrze zorganizowani, jak na kraj, gdzie żołnierz na posterunku stoi bez butów.

JT: Tak, i z drewnianymi karabinami, przecież ja widziałem...

HW: ...z drewnianymi karabinami. Więc w Solce nam powiedziano, że mamy jechać do miejscowości takiej leczniczo-letniskowej, która się nazywała Kempolon ${ }^{26}$.

JT: To gdzieś koło Carmen-Silva, koło Mamaia? Nad morzem, czy nie?

HW: Nie. W głębi lądu, to nie było daleko.

JT: A w jakim kierunku Państwo jechaliście? W stronę Bukaresztu?

HW: W stronę Bukaresztu, tak.

JT: Tak. To wszyscy tak jechali.

HW: Bo jak nas potem w Solce wezwali i kazali wybrać miejscowość, gdzie chcemy osiąść, bo nie wiadomo (prawda), czy osiadamy na tydzień, czy na rok, tośmy wybrali Ploeszti, niedaleko Bukaresztu, to było zagłębie naftowe, gdzie (czy mówi się: zagłębie naftowe...?)

JT: ...zagłębie naftowe, tak... Ploeszti, jedno z najbardziej znanych w Europie.

HW: ...i eksploatowane przez firmę amerykańską „Romano-Americana”, gdzie inżynierami byli Amerykanie i Anglicy. I ktoś nam powiedział, że są tam także inżynierowie Polacy, więc oczywiście to nas... bo byliśmy bez pieniędzy, bo nam Rumuni zmienili tylko trochę złotych, i w ogóle bez żadnego oparcia, bo nie można było jechać...

JT: ...i bez kontaktów z ludźmi... to jest to najważniejsze, bo nikt z Państwa na pewno po rumuńsku nie mówil, prawda?

HW: Nie! A poza tym nie wolno było jechać do Bukaresztu ani do Czerniowiec. Tego absolutnie nam zabraniano, nawet jak przez moment żeśmy wybierali tę miejscowość na jakiś pobyt. Więc do Ploeszti. Ach! W drodze do Ploeszti mieliśmy bardzo taką dla mnie niezapomnianą przygodę, mianowicie: w miejscowości Bacău, gdzie chcieliśmy zanocować, nie było żadnego miejsca, nie było ani w hotelu, ani w prywatnych domach pokoju. I szofer w jakimś barze poznał jakiegoś Rumuna (jak oni rozmawiali, nie wiem, ktoś tam tłumaczył pewnie), który się zaofiarował nas przyjąć na noc, u swoich krewnych. Więc wsiadł do samochodu i prowadził samochód. Jechaliśmy najpierw przez to miasteczko, potem zupełnie w czarnej pustce. Zrobiło nam się oczywiście trochę nieprzyjemnie. Uchodźcy, oczywiście każdy ma coś przy sobie z jakichś skarbów, które wywiózt, więc sobie myśleliśmy: może ten Rumun nas wywozi na pustkowie, żeby nas

${ }^{26}$ Właściwa nazwa brzmi Kimpulung; kurort wypoczynkowy i uzdrowisko klimatyczne na Bukowinie; przed pierwszą wojną światową mieszkało tam kilkuset Polaków. 
obrabować? Dość długo jechaliśmy, w końcu zajechaliśmy do jakiegoś takiego podmiejskiego domu, on wysiadł, poszedł, zastukał, otworzyła drzwi kobieta, on jej coś powiedział i ona otworzyła te drzwi szerzej, i zaprosiła nas do domu. Weszliśmy, mnie się wydaje, że od razu z ulicy do sypialni, w której były dwa łóźka - jedno niepościelone, jakby ktoś właśnie wstał z tego łóźka, a w drugim spała matka tej pani domu. I ona nam pokazała, że to tutaj. Nasz nocleg to tutaj. W tych właściwie...

JT: ...nocleg w warunkach wojennych.

HW: Nocleg w warunkach wojennych... i (muszę powiedzieć) pierwszy raz w życiu spaliśmy w ciepłych jeszcze łóżkach od...

JT: ...poprzedniego właściciela...

HW: ...od poprzedniego lokatora. Nie wiem, gdzie te panie spały, ale w każdym razie nas przenocowały.

JT: No, okazały serca dużo, jak dla obcych...

HW: ...okazały serca dużo i dały nam śniadanie następnego dnia, i kiedy chcieliśmy płacić, to powiedziały, że one nie wezmą od nas ani grosza, bo one także były uchodźczyniami.

JT: W jakim kierunku Państwo dalej pojechaliście? Ciągle w stronę Bukaresztu? Nie, już na Ploeszti, tak?

HW: Na Ploeszti. A Ploeszti jest niedaleko Bukaresztu właściwie. No więc jechaliśmy do Ploeszti. I w Ploeszti nic! Inżynierów Polaków nie ma. Znalazł się tylko pan Szymanowski ${ }^{27}$, stryj Karola, który był inżynierem-emerytem, w niczym nam nie mógł pomóc, sam (zdaje się) był w trudnych warunkach, ale przypadkiem zupełnie zapoznał nas z innym inżynierem Polakiem, który szukał pośród uchodźców wiadomości o żonie i synu, których zostawił w Małopolsce Wschodniej. I ten pan przyszedł do nas i powiedział: „Ja mam znajomego inżyniera, Anglika, który powiedział, że on by przyjął małżeństwo z dzieckiem na czas wojny, for the duration" ${ }^{\prime 28}$. No więc myśmy mogli tylko się spytać, czy by przyjął małżeństwo bez dziecka, na co on sam nie mógł dać odpowiedzi, ale następnego dnia Charlie Brasier, angielski inżynier „Romana-Americana”, przyjechał po nas autem i zabrał nas do swojego domu i do swojej uroczej żony, Cory [?], która była Rumunką.

JT: A to Państwa było trzy osoby, prawda?

HW: Nie, moja siostra została we Lwowie, żeby wrócić z powrotem do Warszawy i połączyć się z rodzicami. Nie chciała wyjechać za granicę.

${ }^{27}$ Wierzyńską zawiodła tu pamięć - mógł to być któryś z kuzynów Karola Szymanowskiego bądź któryś ze stryjecznych braci (nie udało się jednak tego ustalić), trzej stryjowie kompozytora bowiem już wówczas nie żyli.

${ }^{28}$ Ang.: dosłownie - na czas trwania [wojny]; tu: na przetrwanie. 
JT: To Wyście byli tylko we dwójkę, tak?

HW: Tylko byliśmy we dwójkę, ale znaleźli się też Hemarowie. Hemar i Norblinowie.

JT: Tam w Ploeszti?

HW: W Ploeszti. Na razie wziął tylko ten Brasier nas samych, ale myśmy potem ich urządzili bardzo szybko w tej pustej właściwie kolonii, bo wszystkie żony i rodziny były wyewakuowane ${ }^{29}$. No więc właściwie ten cudowny dom (bo mieli bardzo ładny dom), służba, cisza, spokój, znowu te jabłka spadające z drzew, cudownie czyste łóżka, własny pokój, wszystko się wydawało właściwie też rodzajem koszmaru. Bo wtedy z wielką siłą przyszły różne myśli o tym, cośmy stracili, o tym, co się stało z krajem.

JT: No i czarne myśli o przyszłości.

HW: Zupełna niepewność przyszłości. No i poza tym zmartwienie o tych, którzy zostali w Polsce, o bliskich. Ten (jakby go nazwać) koszmarny błogostan trwał jakieś trzy tygodnie i państwo Brasier wzięli nas do samochodu i zawieźli do Bukaresztu, i zostawili nas pod opieką dyrektora „Romana-Americana”, pana Mattingleya, i myśmy tam zaczęli się starać o wizę. Na razie nie bardzo to szło, nie było żadnej pomocy z polskiej strony, aż w końcu Francuzi uprzejmie nam pomogli. Taki był major Egon [?] i pułkownik Arbitre [?], i oni nas włączyli do... personelu (jakby powiedzieć) lotników polskich. I wyjechaliśmy koleją, przez chyba Włochy? Jugosławię, Włochy!

JT: Jugosławię, Włochy i Francję.

HW: I do Francji, do Paryża. Bo dostaliśmy wizę francuską.

JT: Kogo zastaliście Państwo w Paryżu? Z kim skontaktowaliście się na miejscu?

HW: Naturalnie pierwsza osoba to był Lechoń, który...

JT: A on tam był jeszcze, czy w międzyczasie z Warszawy przyjechał?

HW: Nie, nie...

JT: On tam jeszcze siedział, tak?

HW: On był w Paryżu...

JT: ...na placówce dyplomatycznej ${ }^{30} \ldots$

${ }^{29}$ W cytowanym liście Wierzyńskiej do Hemara jest nawiązujący do tego fragment: „Po kilku dniach sprowadziliśmy Was. Ty mieszkałeś u Younga, Norblinowie u Maxwella" (Ja, kabareciarz, s. 83).

${ }^{30}$ Jan Lechoń mieszkał w Paryżu od kwietnia 1930 roku, od maja 1931 roku zatrudniony oficjalnie jako referent propagandowy Ambasady RP, faktycznie w funkcji attaché kulturalnego. 
HW: Lechoń..., no, Łukaszewicz ${ }^{31} \ldots$ już wtedy nie był ambasadorem, on już był prywatną osobą, tak chyba, prawda? Zamieszkaliśmy najpierw w PEN Clubie, gdzie było znowu tak bosko, bo PEN Club ma prześliczny lokal. Nie wiem, jak on dzisiaj wygląda, ale wtedy to było cudownie, wszystko świeże, na drzwiach nie było numerów, tylko kwiaty.

JT: Tak, bardzo ładne.

HW: Takie précieu $x^{32}$ strasznie. Tam mieszkaliśmy pewien czas. Kazimierz od razu zaczął pracować, więc nawiązywał znajomości z żołnierzami, oficerami i lotnikami polskimi. Wiem, że tam do nas, do tego PEN Clubu, przychodził ten właśnie Dudwa ${ }^{33}$, który opowiadał Kazimierzowi swoje przygody, które są opisane w opowiadaniu Puchacz. To opowiadanie wchodzi w skład Pobojowiska, potem wydanego. Kazimierz dość długo nad tym...

JT: ... a czy to było wydane... Pobojowisko było wydane w Paryżu czy w Londynie już?

HW: W Ameryce! Tak. W 44 roku „Roy” wydał.

\section{Zamieszkaliśmy} najpierw w PEN Clubie, gdzie było znowu tak bosko
JT: I Państwo tam, jak długo-ście byli w Paryżu? Przez rok przynajmniej, nie? Czy wcześniej? Wyście byli Państwo aż do tragedii Francji?

HW: No, przyjechaliśmy, tak. Potem wynajęliśmy [mieszkanie] wspólnie z Matuszewskimi ${ }^{34}$ na Avenue President Wilson. Ja pracowałam w „Wiadomościach” jako sekretarka, a Kazimierz pracował wtedy nad tą książką, nad Pobojowiskiem, i pisał wiersze. $\mathrm{Z}$ tego okresu ja sobie tutaj odnotowałam mniej więcej wiersze...

JT: To znaczy, przypominam, okres paryski, tak?

HW: To jest okres paryski, tak... [dtuższa chwila przerwy] ...tu będziemy musieli wycinać tę przerwę...

JT: Nic nie szkodzi. Nam chodzi o informacje, które wprost z pierwszej ręki są, kolejność nie jest ważna.

HW: Tak. Zaraz, bo ja chcę te wiersze mniej więcej wymienić, które Kazimierz pisał we Francji... [stychać szelest kartek]

JT: No, było ich na pewno bardzo dużo tam, prawda?

\footnotetext{
${ }^{31}$ Mowa o Juliuszu Łukasiewiczu (1892-1951), dyplomacie, w latach 1936-1939 ambasadorze RP w Paryżu.

32 Franc.: wyszukane, sztuczne.

${ }^{33}$ Hieronim Franciszek Dudwał (1913-1940), porucznik pilot Wojska Polskiego; w kampanii wrześniowej walczył w 113. eskadrze myśliwskiej; zginął w locie bojowym nad Francją.

${ }^{34}$ Zob. przypis 12. Żoną Matuszewskiego była Halina z Konopackich (1900-1989), lekkoatletka dyskobolka, zdobywczyni pierwszego polskiego złotego medalu olimpijskiego na Igrzyskach w Amsterdamie w 1928 roku; autorka wierszy.
} 
HW: Bardzo dużo, ale...

JT: ... bo to był bardzo płodny okres zresztą w życiu Kazimierza.

HW: ...tak. Via Appia to był ten chyba najważniejszy wiersz z tego okresu, potem...

JT: To do innych wierszy możemy dojść później, jak będziemy rozmawiali o twórczości Kazimierza, prawda?

HW: O, Łuk Triumfalny, Sekwana, Rozmowa z przyjezdnymi, Widok z okna, Pielgrzymom 1940 roku, Wróć nas do krajü35 i wykańczał też Barbakan warszawski, no a ciagle pracował nad Pobojowiskiem. Ten Barbakan potem Tyszkiewicz ${ }^{36}$ wydał w Nicei. Bardzo pięknie. O tym Pobojowisku... Kazimierz z tego okresu, początków wojny, wybuch wojny sam opisał właśnie we wstępie do Pobojowiska, jak to przyszło, a poza tym też mówił o tym, jak powstawało Pobojowisko, że praca nie była zamierzona jako historia kampanii 39 roku, że właściwie ważne wydarzenia zostały pominięte, a Kazimierzowi chodziło o autentyczność świadectw.

JT: I oddanie atmosfery prawdziwej... I pisał aż do czerwca, prawda? To znaczy aż do czasu, kiedy Państwo-ście opuścili Francję w drodze do Brazylii, tak?

HW: Tak. W drodze, jeszcze bardzo skomplikowanej drodze do Brazylii.

JT: To znaczy Państwo właściwie do Portugalii przyjechali, tak?

HW: Myśmy najpierw wyjechali, bo strasznie to było... Myśmy dość długo zostali we Francji, bo nie mogliśmy dostać żadnej wizy.

JT: No, ja wiem, znam to.

HW: Pojechaliśmy najpierw do Biarritz w nadziei, że ktoś tam, może ambasada, pomoże, ktoś tam, znajomi, Leszek ${ }^{37}$, Mohl ${ }^{38}$ i tak dalej, ale to się okazało niemożliwe. Oni wyjechali, patrzyliśmy na to, jak oni wyjeżdżali, potem też i Strzetelscy ${ }^{39}$ byli tam między tymi uchodźcami i myśmy wrócili przez Lourdes, pojechaliśmy do...

JT: ...do Tuluzy...?

HW: ... nie, nie tak blisko, pojechaliśmy do Nicei... By znowu gdzieś osiąść. Żadnych zniką nadziei.

${ }^{35}$ Via Appia i inne wymienione tu wiersze weszły do tomu Ziemia-wilczyca (Londyn 1941).

${ }^{36}$ Samuel Tyszkiewicz (1889-1954), typograf, drukarz i wydawca; w 1926 roku założyciel Oficyny Florenckiej, w latach 1940 -1947 posiadał także drukarnię w Nicei; tu w 1940 roku ukazał się poemat Wierzyńskiego Barbakan warszawski.

Jan Lechoń, właśc. Leszek Serafinowicz.

${ }^{38}$ Aleksander Mohl (1899-1954), ekonomista, dyplomata; przed wojną sekretarz Ambasady RP w Paryżu.

${ }^{39}$ Stanisław Strzetelski (1895-1969), przed wojną dziennikarz, wydawca, poseł na Sejm z ramienia Narodowej Demokracji; w 1940 roku w Paryżu był pracownikiem Ministerstwa Informacji i Dokumentacji rządu RP; po klęsce Francji pracował w Lizbonie w Komitecie Pomocy Uchodźcom Polskim. Jego żoną była Janina z Mękarskich (1899-1992). 
JT: A nikt się nie spodziewał, że Francja padnie tak szybko.

HW: Nie, ale już był taki nastrój. Jakeśmy wyjeżdżali 12 [czerwca] z Paryża ${ }^{40}$, to Francuzi uciekali i uciekali w bardzo taki specjalny sposób, mianowicie z materacami na samochodach.

JT: Tak, ja pamiętam. Widziałem te obrazy na szosach.

HW: Pamięta Pan to? To było takie dla nas pouczające, bo myśmy w Polsce byli ostrzeliwani, ale nikt nie pomyślał, że można materac umieścić na samochodzie.

JT: Ja pamiętam, jak jechałem gdzieś do Tuluzy, przed nami jechał bardzo elegancki samochód otwarty, na którym była wanienka mała dla dziecka i cielę.

HW: O Boże!

JT: W takim popłochu oni uciekali.

HW: Biedne cielę! [śmiech]

JT: To znaczy Państwo kiedyście opuścili Francję? W czerwcu?

HW: W sierpniu, dopiero w sierpniu.

JT: W sierpniu 1940. A to już Niemcy byli tam!

HW: Niemcy byli i już to południe Francji też było lekko zagrożone.

JT: Znaczy zaczęło się Vichy.

HW: Tak. Myśmy nie mogli dostać visa de sortie $e^{41}$, wyjazdowej wizy, i trzeba było się z tym zwracać do Vichy, ale nie bardzo mieliśmy odwagę. No, w końcu tam przez jakiegoś konsula przypadkowo po prostu w Perpignan, bośmy wyjechali na granicę, dostaliśmy wizy.

[cz. II]

JT: Proszę Pani, więc w końcu mieliście Państwo wszystkie wizy i zaczynał się drugi akt odysei.

HW: Tak, przyjechaliśmy do granicy hiszpańskiej i zdawało się, że już jest wszystko załatwione. Tymczasem tam nas spotkała niespodzianka, mianowicie: Hiszpanie przepuszczali tylko 25 osób przez granicę i tylko Szwajcarów i Amerykanów. Więc znowu...

${ }^{40}$ Upadek Paryża nastąpił 14 czerwca 1940 roku

${ }^{41}$ Franc.: wiza wyjazdowa. 
JT: A reszta co, czekała?

HW: Reszta czekała. Tam czekał z nami zresztą Kisling ${ }^{42}$, który też wyjeżdżał. No, beznadziejnie. Więc chodziło się ciagle do tego okienka z pytaniem, czy nie zmieniły się przepisy, ale się nic nie zmieniło, i Kazimierz telegraficznie się porozumiał z Sumlanowskim ${ }^{43} \mathrm{w}$ Madrycie, który bardzo uprzejmie i przyjaźnie załatwił imienną wizę dla Kazimierza przez granicę, imienne pozwolenie na przejazd granicy. No i tak się stało. Najpierw oni tego nie ogłosili nigdzie, więc myśmy znowu, chodząc do tych okienek, pytali się, czy nie ma dla nas wizy, i raz tak poszliśmy i okazało się, wiza była i przejechaliśmy. Pojechaliśmy do Madrytu, gdzie znowu nastąpił jeden z tych koszmarnych błogostanów, że na całym świecie spokój i że my zawieszeni w powietrzu. Więc właściwie te trzy dni, kiedy byliśmy w Madrycie, to spędziliśmy cały czas w Prado, pojechaliśmy też do Toledo, które tak wygląda jak na obrazach El Greca, i stamtąd do Portugalii, gdzie był koniec Europy, gdzie było mnóstwo zdenerwowanych uchodźców i bardzo dużo też Polaków.

JT: A jak były Państwa warunki finansowe? Czy wyście byli w porozumieniu z jakimś komitetem uchodźczym? Bo przecież wtedy nie można było zarobić niczego.

HW: Nie, oczywiście nie. To była ciągła pomoc od jakichś urzędów polskich, tak. Ja nie powiedziałam jeszcze jednej rzeczy tam poprzednio, że myśmy (czy powiedziałam....?), że myśmy dostali depeszę od Strzetelskiego w Nicei.

JT: Nie.

HW: Nie. Voyage séjour Brasil assuré vous et Malczewskít ${ }^{44}$ I to, to właściwie dało nam siłę i energię, żeby się starać o te wszystkie inne wizy.

Pojechaliśmy do Madrytu, gdzie znowu nastąpit jeden $\mathrm{z}$ tych koszmarnych błogostanów

JT: Tak, ale czy Państwo na podstawie tego telegramu dostaliście wizy, czy to musiała być jakaś...

HW: To pomagało jako konkretna rzecz, która świadczy, że...

JT: ...znaczy w konsulacie brazylijskim, tak?

HW: Nie, nie, jeszcze w konsulacie brazylijskim nie, jeszcze Hiszpania i Portugalia.

JT: Ano, tak, tak...

HW: ...że jedziemy, że jedziemy gdzieś, że nie zatrzymamy się w Hiszpanii, nie zatrzymamy się w Portugalii na dłuższy pobyt. Więc potem pojechaliśmy do Portugalii, gdzie

${ }^{42}$ Moïse (właśc. Mojżesz) Kisling (1891-1953), malarz polsko-żydowskiego pochodzenia; w obawie przed aresztowaniem w 1940 roku przez Hiszpanię i Portugalię wyjechał do Stanów Zjednoczonych, mieszkał w Nowym Jorku i w Hollywood, do Francji powrócił w 1946 roku.

${ }^{43}$ Chodzi o Mariana Szumlakowskiego (1893-1961), dyplomatę, od 1933 roku ministra pełnomocnego na placówce w Lizbonie, w 1935-1944 posła RP w Madrycie; po wojnie pozostał na emigracji.

${ }^{44}$ Franc.: podróż, pobyt, Brazylia zapewniony, wy i Malczewski. - Mowa o Rafale Malczewskim (1892-1965), malarzu i prozaiku; do Rio de Janeiro dotarł w styczniu 1941 roku. 
okazało się też, że to tak nie było automatycznie wszystko załatwione z tą Brazylią, no ale w końcu Brazylia wyszła. I kiedy to było? Mnie się zdaje, że to było 13 października ${ }^{45}$, myśmy wsiedli na okręt, który się nazywał „Serpa Pinto” i pojechali do Rio.

JT: Do Rio. Proszę Pani, czy Państwo pojechaliście sami, czy byli jacyś inni, poeci, malarze?

HW: Z nami, tak.

JT: Grupa była jakaś polska, tak?

HW: Tuwim był już w Rio, a z nami jechali tym statkiem „Serpa Pinto” Czermańscy ${ }^{46}$. Nie, przepraszam, nie. Czermańscy dopiero jechali z nami z Brazylii do Nowego Jorku. Tam jechała cała grupa polska: jakiś pan Skalski, taki (zdaje się) adwokat, którego bodajże wdowa jest tutaj, w Nowym Jorku.

JT: A Lechoń? Gdzie był Lechoń w tym czasie?

HW: Lechoń, mnie się zdaje, że...

JT: Nie przyjechał z Państwem?

HW: Nie, nie.

JT: Ale on był w Brazylii też, prawda, zdaje się, nie?

HW: On był w Brazylii, tylko nie pamiętam, czy był przed nami ${ }^{47}$, czy był już po nas?

JT: W każdym razie w grupie tej nie było nikogo z poetów. To była grupa ogólna taka, prawda?...

HW: ...to była grupa ogólna. Mieliśmy zresztą tzw. turystyczne kabiny, bardzo marne, jedzenie okropne, no i takie normalne uchodźstwo. Tak jak prawdopodobnie...

JT: ...tak, tak. Jak długo trwała podróż?

HW: Trzynaście dni chyba.

JT: W tych warunkach strasznych?

HW: W tych! Troszkę się poprawiły dzięki panu Skalskiemu, który wyrobił dla nas stół w pierwszej klasie, tak że chodziliśmy jeść do pierwszej klasy.

\footnotetext{
${ }^{45}$ Podróż Wierzyńskich rozpoczęła się 13 listopada 1940 roku, w Rio de Janeiro znaleźli się 28 listopada.

${ }^{46}$ Zdzisław Czermański (1901-1970), rysownik i prozaik, i jego żona Janina z Margulesów (1911-2004).

${ }^{47}$ Lechoń oraz Stefania i Julian Tuwimowie dotarli z Lizbony do Rio de Janeiro 4 sierpnia 1940 roku.
} 
JT: Aha, tak, to już było troszkę lepsze jedzenie.

HW: No, było. Tak, było znacznie.

JT: A chorowaliście Państwo bardzo? Burze jakieś, czy coś?

HW: Nie, ja szalenie chorowałam po wyjeździe z Lizbony, potwornie, przez 24 godziny, a potem jak ręką odjął. Lepiej się czułam niż potem, jadąc z Brazylii do Ameryki.

JT: Do Stanów Zjednoczonych.

HW: Gdzie niby morze było jak stół.

JT: No to teraz trzeci etap podróży: Brazylia. Może nam Pani powie łaskawie, kto Was tam przyjął?

HW: Trzeci etap - Brazylia.

JT: Zajęli się Wami? I jak Wam życie płynęło?

HW: No więc, czekali na nas Tuwimowie i nie pamiętam, czy Lechoń był, czy nie. Zamieszkaliśmy w pensjonacie państwa Sworakowskich, mnie się zdaje... Nie, Sworakowski to był... wszystko jedno, mniejsza...

JT: W każdym razie w polskim pensjonacie, prawda?

HW: W polskim pensjonacie, państwa S... [dtuga chwila milczenia] ...bardzo niewyraźnie napisałam.

JT: Nic nie szkodzi.

HW: A już wiem, Stamirowskich ${ }^{48}$. A Czermańscy razem z Tuwimami, i potem z Lechoniem, wzięli mieszkanie umeblowane i prowadzili gospodarstwo ${ }^{49}$. Tam Kazimierz, wiem, też miał jakieś rozmowy, bodajże z panem Łosiem ${ }^{50}$, który był z polskiej marynarki, na temat wojny, i jedno z opowiadań jest z tych rozmów w Pobojowisku.

JT: Tam było dużo jednak Polaków. Tam była Dora Kalinówna, później przyjechała?

HW: Później, ja jej nie pamiętam.

48 Tu Wierzyńską we wspomnieniach zwiodło podobieństwo nazwisk; według cytowanego już jej listu do Hemara w pensjonacie p. Sworakowskiego mieszkali Wierzyńscy w Rumunii, w Kimpulung, „za normalną pensjonatową opłatą”; o pensjonacie pp. Stamirowskich w Rio de Janeiro brak danych. 1966).

${ }^{49}$ Barwny opis tego wspólnego zamieszkiwania przedstawił Czermański we wspomnieniowej książce Kolorowi ludzie (Londyn

${ }^{50}$ Andrzej Łoś (1899-1962), hrabia herbu Dąbrowa, komandor podporucznik; walczył w obronie Helu; oskarżony o niehonorowe skorzystanie ze zwolnienia z Oflagu, bez prawa służby w Polskiej Marynarce Wojennej, wyjechał w 1940 roku do Brazylii; w 1945 roku został zrehabilitowany. Oparte na jego relacji opowiadanie to Garść wody. 
JT: Tam był reżyser Teatru Narodowego, zdaje się, który...

HW: ...był, ale on, zdaje się, ...jak on się nazywał?

JT: No właśnie, w tej chwili zapomniałem, ale to nieważne jest. O to chodzi: osiedlił się i stworzył jakiś wielki teatr polski tam ${ }^{51}$.

HW: Tak, bodajże Eichlerówna ${ }^{52}$ tam była.

JT: Eichlerówna tam była, nie polski teatr, tylko on w brazylijskim się później odznaczył.

HW: Tak, to było później [dtuższa chwila milczenia], Boże, to nazwisko mam na końcu języka...

JT: On był w Polsce eksperymentatorem tak samo. W Teatrze Nowym był.

HW: Było bardzo dużo przemysłowców polskich.

JT: Tam był rzeźbiarz, Zamoyski ${ }^{53}$, tak?

HW: Rzeźbiarz Zamoyski?

JT: W tym okresie czy dopiero później?

HW: Nie, to później.

JT: A to później dopiero, tak. W każdym razie Polonia, intelektualna Polonia, była duża tam, prawda?

HW: Tak... No, opiekowali się tym wszystkim w pewnym sensie państwo Czartoryscy ${ }^{54}$, tak że u nich na przykład odbywały się jakieś takie wieczory autorskie poetów, którzy tam byli, pisarzy.

JT: Jak Wam życie płynęło? Jak długo przede wszystkim Państwo-ście byli tam w Brazylii?

HW: Do Ameryki przyjechaliśmy 2 czerwca, więc to...

${ }^{51}$ Chodzi o Zbigniewa Ziembińskiego (1908-1978), przed wojną aktora i reżysera, m.in. w Teatrze im. J. Słowackiego w Krakowie i Teatrze Polskim w Warszawie; od 1941 roku przebywał w Rio de Janeiro, gdzie działając jako aktor, reżyser i dyrektor teatralny, zyskał miano ojca teatru brazylijskiego.

52 Irena Eichlerówna (1908-1990), wybitna aktorka dramatyczna; od 1940 roku przebywała w Rio de Janeiro; w 1948 roku wróciła do Polski.

${ }^{53}$ August Zamoyski (1893-1970), rzeźbiarz; po wybuchu wojny wyjechał do Rio de Janeiro (był tam jednym z pierwszych wojennych uchodźców), gdzie prowadził szkołę rzeźby według własnych metod oraz kierował kursem rzeźby w Akademii Sztuk Pięknych.

${ }^{54}$ Książę Olgierd Czartoryski (1888-1977) i jego żona Mechtylda Mechthildis Maria arcyksiężna Habsburżanka-Lotaryńska (1891-1966); prezes Czerwonego Krzyża i Unii Kulturalnej; ambasador Zakonu Maltańskiego przy rządzie brazylijskim; po wojnie traktowany był przez korpus dyplomatyczny w Brazylii jako przedstawiciel Wolnej Polski. 
JT: ...znaczy co najmniej z siedem miesięcy.

HW: To było całą zimę. Tak, tak. Przeszło sześć miesięcy.

JT: I co zdecydowało o przyjeździe Państwa do Nowego Jorku? Co Was skłoniło do tego?

HW: Ach, szalona odległość od całego świata, od spraw polskich, mimo tej kolonii polskiej, no, chcieliśmy koniecznie jechać do Stanów, ale to było trudne, dlatego że konsulaty się bardzo broniły. Mówili: skąd wy wiecie, że będziecie w Stanach szczęśliwsi niż jesteście w Brazylii?

JT: Znaczy amerykańskie konsulaty tak mówiły, tak...

HW: ...amerykańskie. Albo po prostu mówili nam, że kwota ${ }^{55}$ jest przeciążona, oversubscribed $^{56}$, i że nie mogą nam dać. I nagle dowiedzieliśmy się, Tuwim pierwszy, a potem my, że w São Paulo jest konsul, pan Jordan, który bardzo uprzejmie i życzliwie się odnosi do takich uchodźców jak my i daje wizy. Więc Tuwimowie dostali wizę najpierw ${ }^{57}$, a potem myśmy pojechali i w ciągu jednego dnia mieliśmy obietnicę wizy, a potem wizę samą, zanim jeszcze nasze dossier zdążyło przyjść z Rio, bo w Rio składaliśmy już petycję o wizę. No i trzeba by od tego 2 czerwca odjąć trzynaście dni, bo ta droga też mniej więcej trwała trzynaście dni, jechaliśmy statkiem „Argentina” linii Moor-McCormack. Tamte rzeczy się tak utrwaliły w mojej pamięci.

JT: Tak, no, oczywiście, to jest raz na całe życie. To się pamięta, te wszystkie rzeczy. Zwłaszcza, że po okresie tak trudnym, do którego się często wraca pamięcią. Proszę Pani, a jak załatwiliście bilety? Czy ktoś zapłacił bilety? Jakiś komitet amerykański, czy nie, czy wyście musieli sięgać do oszczędności?

HW: Nie, myśmy nie mieli, niestety, oszczędności.

JT: No, właśnie, nikt nie miał.

HW: Ale to ciągle jakieś fundusze polskie. Już wtedy bodajże został stworzony ten Fundusz Kulturalny ${ }^{58}$. Tak że to były pieniądze publiczne.

JT: No, nie mogły być prywatne, bo nikt nie mógł pracować w Brazylii, w jakim języku?

HW: Bo nikt nie mógłby tyle dać.

${ }^{55}$ Chodzi o tzw. kwotę imigracyjną, wprowadzoną w latach dwudziestych XX wieku, tj. określoną liczbę imigrantów, którym w danym roku pozwalano na przyjazd i osiedlenie się w Stanach Zjednoczonych.

${ }^{56}$ Ang.: przekroczona.

${ }^{57}$ Tuwimowie dotarli z Brazylii do Nowego Jorku w ostatnich dniach maja 1941 roku.

${ }^{58}$ Mowa o Funduszu Kultury Narodowej - jako instytucja o charakterze fundacji państwowej działał w latach 1928-1939, w czasie wojny nadzorowany przez Ministerstwo Informacji i Dokumentacji m.in. wypłacał zasiłki twórcom na uchodźstwie. 
JT: Proszę Pani, to czwarty etap się zaczął w takim razie na wiosnę, tak? Raczej w lecie 42 roku.

HW: Nie, 41 !

JT: 41, przepraszam, tak.

HW: Przyjechaliśmy do Ameryki razem z Czermańskimi. Oni byli na tym statku „Argentina”. Najpierw pojechaliśmy do konsulatu, gdzie nam dano pokój, potem Węgrzynek... był taki Maksymilian Węgrzynek ${ }^{59}$, właściciel „Nowego Świata”, bardzo wybitny...

JT: ...tak, znam, on się właściwie opiekował poetami, dziennikarzami, tak...

HW: ...bardzo wybitny, inteligentny człowiek. Piłsudczyk zresztą. On nas zaprosił do swojego domu w Forest Hills.

JT: Znam ten dom, bo mieszkam naprzeciw tego domu teraz.

Przyjechaliśmy do Ameryki

razem

z Czermańskimi

HW: Tak, bardzo blisko. Ja stamtąd poznawałam Forest Hills. A sam wyjechał na farmę koło Wingdale w stanie Nowy Jork. No więc myśmy tam mieszkali przez wakacje i ja się tak rozglądałam, bardzo się nam podobało to Forest Hills, bardzo dobra komunikacja z Nowym Jorkiem, i wynajęłam mieszkanie w takim dwurodzinnym domku, na górze maleńkie trzy pokoje, i takie samo mieszkanie wynajęłyśmy dla Czermańskich, troszkę dalej, na Ascan Avenue.

JT: A Tuwimowie mieszkali gdzie wtedy, na Manhattanie?

HW: Oni mieszkali w Manhattanie na 72 ulicy, potem już nie wiem, ja dobrze ich adresów nie znam, bo te stosunki z Tuwimami, dobre, trwały dość krótko, bo potem Tuwim się zaczął tak szalenie ostentacyjnie, wyraźnie orientować na Rosję. To nie tylko była Polska, ta inna, tylko Rosja, co denerwowało i Lechonia, i Kazimierza, więc się te stosunki bardzo rozluźniły.

JT: A Lechoń przebywał często u Was? Z nim przyjaźniliście się najbardziej Państwo, prawda?

HW: Tak, najbardziej. To były codzienne prawie telefony i przychodził do nas. Potem jak mieszkaliśmy na wsi, to przyjeżdżał też z wizytami na kilka dni.

JT: Ale do Sag Harbor Państwo wyjechaliście później znacznie, prawda?

59 Maksymilian Węgrzynek (1892-1944), działacz polonijny i niepodległościowy, od 1914 roku przebywający w Stanach Zjednoczonych; od 1922 roku wydawca, a później prezes spółki wydającej „Nowy Świat”, największą polską gazetę w USA w 1942 roku współzałożyciel Komitetu Narodowego Amerykanów Polskiego Pochodzenia, w 1943 roku - Instytutu J. Piłsudskiego w Ameryce, w 1944 roku - wiceprezes nowo powstałego Kongresu Polonii Amerykańskiej. 
HW: Aaa, do Sag Harbor to dużo później... więc mieszkaliśmy prawie 10 lat na Ascan Avenue. A potem wyjechaliśmy do Stockbridge' ${ }^{60}$, bo Kazimierz zaczął pisać książkę o Chopinie i jakoś w Nowym Jorku, bardzo rozpraszany tymi ciągłymi telefonami i widywaniem ludzi, jakoś mu ta praca nie szła. I pan, który się zresztą przyczynił bardzo do napisania tej książki, pan Percival, miał posiadłość na wsi, w Stockbridge’u, posiadłość, którą kupił od Rodzińskich ${ }^{61} \ldots$

JT: ...a Rodzińska jeszcze dalej tam mieszka, prawda? Znaczy, ma tam jeszcze część posiadłości, nie?

HW: Nie, oni sprzedali Stockbridge właśnie temu panu, a kupili większą (zdaje się) posiadłość, dawny teren golfowy w Lake Placid.

JT: Aaa, w Lake Placid, tak, bo ja pamiętam, w Stockbridge oni byli, ale to było w roku 42, coś takiego. Proszę Pani, jak w zasadzie ukształtowały się pierwsze lata Państwa w Stanach Zjednoczonych?

HW: No więc zacznę od początku: osiedliliśmy się w Nowym Jorku i wynajęliśmy mieszkanie w Forest Hills, dzielnicy willowej pod Nowym Jorkiem. Rozpoczął się okres czekania na powrót do Polski, na koniec wojny. Zdawało się nam, że wszystko się skończy dobrze. Był to też bardzo ciężki okres osobisty. Całym sercem zwróceni w kierunku kraju, nadsłuchiwaliśmy wiadomości, które przychodziły coraz gorsze. Kazimierz stracił w czasie wojny pięcioro najbliższych członków rodziny ${ }^{62}$. Inni byli rozsypani po kraju. Był to też czas zabiegów o chleb powszedni. Istniał wtedy Fundusz Kultury Narodowej, który pomagał pisarzom i intelektualistom polskim za granicą, korzystali z niego Kazimierz, Lechoń, Wittlin, na początku Tuwim, aż do czasu, kiedy zdeklarował swoją solidarność z Rosją Sowieckąa ${ }^{63}$. Potem w 1943 roku Lechoń, Kazimierz, Wittlin i Kosidowski stworzyli pismo. Wychodziło najpierw powielane jako serwis literacki dla prasy polskiej, tak zwany „zieleniec” (bo wychodził na zielonym papierze), potem zmieniony na „Tygodniowy Przegląd Literacki Pisarzy z Polski”, wreszcie zaczął się ukazywać jako „Tygodnik Polski”, który wychodził do końca 1947 roku już pod redakcją Lechonia. Na jesieni 43 wyszedł z pisma Wittlin, a wszedł Pan, Pan pamięta, prawda? W lutym 44 roku wystąpił też Kazimierz ${ }^{64}$. W „Tygodniku” Kazimierz drukował swoje

60 Wierzyńska używała tu i w wielu innych wypowiedziach spolszczonej (ti. wymawianej raczej po polsku i odmienianej zgodnie z regułami języka polskiego) nazwy tej miejscowości; w zapisie zgodnym z brzmieniem byłoby to: Stokbridż, w Stokbridżu, do Stokbridża (niczym Białystok). Inne nazwy obcych miejscowości były przez nią nazywane w wywiadzie zgodnie z zasadami poszczególnych języków (np. francuskie Perpignan, angielskie Elmhurst, Lake Placid itd.); jedynie pomyłka w nazwie rumuńskiego miasta Kimpulung mogłaby wskazywać na próbę spolszczonej wymowy.

Arthur Percival z żona Dorota Powers, skrzypaczka, zapewnili Wierzyńskiemu mieszkanie i utrzymanie na czas pisania biografii Chopina; poeta poświęcił im fragment rozdziału Chopin i wiersze z tomu Moja prywatna Ameryka (Londyn 1966). Poprzednimi właścicielami farmy byli Artur Rodziński (1894-1958), wybitny dyrygent, od 1926 roku działający artystycznie w USA, oraz jego żona Halina z Lilpopów (1904-1993), po wojnie w 1948 roku inicjatorka i prezeska Nowojorskiego Komitetu Pomocy Niewidomym w Polsce.

${ }^{62}$ Byli to rodzice Felicja i Andrzej, zmarli w 1944 roku, brat Bronisław i jego syn Jan, zabici w czasie powstania warszawskiego, brat Hieronim, zamęczony w Majdanku, i jego córka Janina, uczestniczka powstania warszawskiego. Ich pamięci poeta dedykował tom Krzyże i miecze (Londyn 1946).

${ }^{63}$ Rząd wstrzymał wypłacanie Tuwimowi zapomogi z Funduszu Kultury Narodowej w marcu 1944 roku.

${ }^{64}$ W istocie „Tygodniowy Serwis Literacki Koła Pisarzy z Polski” wychodził jako maszynopis (na zielonym papierze) już w listopadzie 1941 roku, od 1942 - „Tygodniowy Przegląd Literacki Koła Pisarzy z Polski”; od 1943 w postaci drukowanej jako „Tygodnik Polski”, ostatni numer ukazał się w czerwcu 1947 roku. Wittlin opuścił redakcję we wrześniu 1943 roku, kontestując jego „linię polityczną", w październiku jego miejsce zajął Jerzy Tepa. Lechoń był samodzielnym redaktorem od kwietnia 1944 roku, jednak dopiero w styczniu 1947 roku Wierzyński scedował na niego swoje udziały w piśmie. 
wiersze, a nawet opowiadania, które weszły w skład Pobojowiska, wydanego przez Roy Publishers.

[Tu uszkodzenie nagrania $=$ dtuga cisza na taśmie $]$.

HW: Postanowiliśmy zostać na cały rok, spróbować, jak to będzie w zimie, jaka będzie zima w Londynie. No więc, zima okazała się dobra. Wzięliśmy puste mieszkanie, które ja umeblowałam takimi... z różnych antykwarni. Wtedy te rzeczy nie były takie drogie. [Tu uszkodzenie nagrania = dtuga cisza na támie $]$.

[cz. III]

JT: Proszę Pani, przejdźmy teraz do twórczości Kazimierza w okresie nowojorskim, dobrze?

HW: Dobrze. Więc jeżeli chodzi o wiersze z tego okresu, to pisane w latach 42-45 wyszły w roku 46, wydane przez Bibliotekę Polską, wydawnictwo stworzone też przez pisarzy z Polski, tych samych, którzy założyli „Tygodnik Polski”. Tytuł tego zbioru wierszy był Krzyże i miecze. Były to najboleśniejsze wiersze w całej twórczości mego męża.

Jak nam się zdawało, na Amerykanów nie było czasu
Należą do nich Boże rozpaczy, A więc stato się, Na zajęcie Warszawy przez Rosjan, Na rozwiazanie Armii Krajowej, Krzyknęli wolność, Do sumienia świata, Litania ziemi lwowskiej i Msza żatobna w katedrze nowojorskiej. Jednocześnie ukazały się dwa tomy wcześniejszych wierszy: Ziemia-wilczyca (1941) i Róża wiatrów (42). Także Wspótczesna literatura na emigracji, odczyt wygłoszony w Nowym Jorku w 43 roku $^{65}$. A w 44 już wyszedł zbiór opowiadań z wojny 39 roku pod tytułem Pobojowisko. W Ziemi-wilczycy jest Wstązka z „Warszawianki”, o której zapomniałam powiedzieć poprzednio. Jest to jeden z trzech wierszy napisanych w pierwszych dniach wojny, przed samą wojną. Ten dokładnie 27 sierpnia, ukazał się 3 września jako wkładka do ostatniego numeru „Wiadomości Literackich”. W Róży wiatrów znowu są wiersze, nie wszystkie wprawdzie, pisane i drukowane w pismach przed wojną i zebrane w tom (przed wojną 39 roku) przeznaczony do druku u Mortkowicza. Rękopis został złożony przed samym wybuchem wojny u wydawcy i niestety zginął w spalonej drukarni na Starym Mieście. Tam jest ten piękny wiersz Ktokolwiek jesteś bez ojczyzny: „bo nie ma ziemi wybieranej, // // Jest tylko ziemia przeznaczona, // Ze wszystkich bogactw - cztery ściany, // Z całego świata - tamta strona" ${ }^{66}$.

JT: Proszę Pani, może teraz przejdziemy do wiadomości i opowie nam Pani, jak przedstawiało się życie Państwa w tym okresie?

HW: Był to okres towarzysko czysto polski. Jak nam się zdawało, na Amerykanów nie było czasu. To śmieszne, ale tak było. Widywaliśmy się z Matuszewskimi aż do jego śmierci w 46 roku, z Rajchmanami ${ }^{67}$, którzy dzięki pani Małeckiej, matce Zosi, prowa-

${ }^{65}$ Odczyt wygłoszony 26 kwietnia 1943 roku w ramach zorganizowanego przez Polski Instytut Naukowy w Ameryce cyklu wykładów Historia literatury polskiej; przedruk w: K. Wierzyński, Szkice i portrety literackie, oprac. P. Kądziela, Warszawa 1990.

${ }^{66}$ Cytat stanowi ostatnią strofę wiersza.

${ }^{67}$ Henryk Floyar-Rajchman (1893-1951), legionista, działacz polityczny; w czasie wojny krytyczny wobec rządu gen. W. Sikorskiego, od 1941 roku przebywał w Stanach Zjednoczonych; w 1942 roku współzałożyciel Komitetu Narodowego Amerykanów 
dzili dom bardzo gościnny, i z Lechoniem, który oczywiście tak jak kiedyś w Warszawie dzwonił codziennie i widywał się z nami bardzo często.

JT: A proszę Pani, Państwo się zawsze przyjaźniliście z Lechoniem. Może nam Pani opowie coś więcej o tym równie wielkim poecie.

HW: Więc Lechoń od zawsze był najbliższym przyjacielem Kazimierza i tutaj w Ameryce to trwało dalej. Był on poza tym niesłychanie ważnym przedstawicielem naszej grupy emigracyjnej. Bardzo inteligentny, jak byśmy dzisiaj po angielsku powiedzieli brilliant, dowcipny, morderczo złośliwy, jeśli chciał, wesoły, znany ze swego śmiechu, towarzyski, aż (można powiedzieć) za nadto na jego potrzeby, rozproszony, udręczony, ambitny, zazdrosny, maniakalnie niesprawiedliwy w sądach, mimo swej inteligencji, słowem pełny człowiek. W wiecznych kłopotach finansowych potrzebował patronów i znajdował ich, a raczej je, wśród polskich milionerek. Widząc go w towarzystwie niektórych osób, można było pomyśleć, że nadawałby się świetnie na dworskiego poetę, gdyby istniały za naszych czasów dwory ważniejsze od Waldorf-Astoria czy pałacyków pod Nowym Jorkiem $^{68}$. Lękliwy, nerwowy, przeżywał pod koniec życia panikę przed władzami imigracyjnymi, które ociągały się z przyznaniem mu obywatelstwa Stanów Zjednoczonych. Zginął, właściwie uciekając przed strachem. W polityce był konserwatywnych przekonań, co jasno widać z jego dzienników. Poza tym widywaliśmy się z Czermańskimi, którzy byli naszymi sąsiadami na Ascan Avenue, ze Strzetelskimi - Stanisław pracował w Polish Information Center ${ }^{69}$, był życzliwy, miły, lubił ludzi, lubił im wyświadczać przysługi. Z Amerykanów, jak powiedziałam, znaliśmy właściwie bardzo niewiele osób, oczywiście wierną przyjaciółkę Polski Grace Humphrey ${ }^{70}$, ale poza tym wydawało się, że nie ma dla nich miejsca. To się zmieniło mniej więcej dla nas w 47 roku.

JT: Po tej dygresji, bardzo ciekawej zresztą, chciałbym się jeszcze raz zapytać, jak przedstawiały się dalej warunki życia obojga Państwa?

HW: No więc w 1947 roku zasiłki z Funduszu Kultury się skończyły. Byliśmy bez środków do życia. Wtedy przyszedł nam z pomocą Artur Rodziński, który wymyślił, że Kazimierz powinien napisać biografię Chopina na nadchodzącą rocznicę jego śmierci 1949 roku. Nie tylko miał pomysł, ale znalazł także sponsora, który pomógł nam przetrwać dwa ciężkie lata. Kazimierz niechętnie myślał o tej pracy, ale w końcu zgodził się napisać tę książkę. Zaczął tę pracę w Nowym Jorku, ale mu nie szła. Pan Percival, sponsor tej pracy, zaproponował nam przeniesienie się do Stockbridge’a, w górach albo raczej

Polskiego Pochodzenia, w 1943 roku - Instytutu J. Piłsudskiego w Ameryce; traktowany jako główny ideolog niepodległościowy. Jego żoną była Zofia (1904-1978) z Małeckich, $1^{\circ}$ voto Bagniewska, $3^{\circ}$ voto Kowalska.

${ }^{68}$ Aluzja do korzystania przez Lechonia z pomocy finansowej wdów po amerykańskich milionerach: Cecylii Burr (z Wasiłowskich, 1886-1964), zamieszkującej w Nowym Jorku w reprezentacyjnym hotelu Waldorf-Astoria i w rezydencji w Locust Valley na Long Island, gdzie często bywał poeta, oraz Ireny Cittadini (1898 lub 1903-1976, z Rumelów, $1^{\circ}$ voto Warden). Pierwszej złożył hołd w wierszu Madrygat (pierwodruk w arykule: B. Dorosz, Lechonia wiersze ulotne, „Przegląd Polski”, dodatek „Nowego Dziennika”, Nowy Jork 2001, nr z 8 VI), drugiej dedykował wiesz Rymy częstochowskie (pierwodruk: „Wiadomości”, Londyn 1951, nr 35/36).

${ }^{69}$ Polish Information Center - agenda Ministerstwa Informacji i Dokumentacji rządu RP na uchodźstwie powołana w Nowym Jorku w 1940 roku dla informowania społeczeństwa amerykańskiego o sytuacji w okupowanej Polsce, walce AK w kraju i Polskich Sił Zbrojnych na Zachodzie; działała do połowy 1945 roku, tj. do cofnięcia przez Stany Zjednoczone uznania rządowi polskiemu na emigracji.

${ }^{70}$ Grace Humphrey (1882-1961), amerykańska pisarka, autorka książek o Polsce i jej historii, m.in. Pilsudski, builder of Poland (New York 1936), Poland today (Warsaw 1935), Poland, the unexplored (Indianapolis 1931), Come with me through Krakow (Krakow 1934) i Come with me through Warsaw (Warsaw 1934). 
Stało się już regułą naszego życia, że w najcięższych okresach następowały momenty spokoju i prawie błogostanu wzgórzach Bergshire, gdzie miał kupioną od Rodzińskich farmę, gdzie jeden z dwóch cottage 'ó $^{71}$ był wolny. Przenieśliśmy się na razie na próbę, ale okazało się, że warunki pracy były idealne i po paru miesiącach wyjechaliśmy tam na dobre. Przeżyliśmy nieprawdopodobnie urocze dwa lata. Mieszkaliśmy na skraju lasu, na końcu bocznej drogi od szosy ze Stockbridge’a. Stało się już regułą naszego życia, że w najcięższych okresach następowały momenty spokoju i prawie błogostanu. Tak było również z naszym pobytem w Stockbridge’u. Nasz cottage stał na końcu drogi, jak powiedziałam, która zmieniała się w wąką polną ścieżkę i szła w głąb właściwie puszczy. Nikt poza nami nie mieszkał na tej farmie. Najbliższe światło świeciło się w sąsiedniej posiadłości państwa Morganów o milę od nas. Jedyne żywe istoty na farmie to były dwa konie, którymi zajmował się dojeżdżający robotnik. On również przywoził nam pocztę i zabierał mnie na zakupy w miasteczku. W Stockbridge’u przeżyliśmy takie zbliżenie z przyrodą, jakiego ja w każdym razie nie spodziewałam się w moim miejskim życiu. W zimie spadły ogromne śniegi, do naszego cottagé u podchodziły zwierzęta z lasu, rano oglądaliśmy ich ślady na nieskalanym śniegu. Wieczory pełne były ogromnego nieba i gwiazd, które odczytywaliśmy przy pomocy takiego dość szkolnego, dość naiwnego instrumentu zwanego starfinder $^{72}$. No, ale w każdym razie uwiecznione są w wierszach. Mieliśmy wielką kolekcję płyt z utworami Chopina.

JT: A proszę Pani, Kazimierz już pracował wtedy nad tą książą̧, prawda? Jakie były dalsze dzieje tej książki i co jeszcze Kazimierz pisał?

HW: Tak, więc on zaczął pracować nad tą książką i tutaj praca w Stockbridge’u poszła dobrze - codziennie odrabiał swoje pensum - ale tęsknota za wierszami była zbyt wielka, żeby ich nie pisał, więc dla odpoczynku pisał wiersze. I były to zupełnie inne wiersze niż dotąd, wiersze, które pewien krakowski krytyk nazwał tyrtejskimi. Znaczy wierszy patriotycznych, wierszy o kraju. Te nowe wiersze wyszły potem w tomie Korzec maku, wydanym przez Veritas w 51 roku. Sam Kazimierz o tych wierszach mówił, że stały się dla niego odnowieniem. „Porzuciłem dawne tematy i dawną formę, i poczułem się nagle śród nowych obszarów poetyckich [o nieprzeczuwanych urokach]. Po Krzyżach i mieczach, które - jak pięć innych książek wydanych podczas wojny - wypełnione były wierszami o Polsce i jej losach, zrozumiałem, że [już] nic do tych wierszy dodać nie mogę. Znalazłem się, jak my wszyscy, sam na sam z naszą klęską, bez żadnego wpływu na cokolwiek, w pełnym poczuciu obezwładnienia. I wtedy właśnie, na tym odludziu, w ciszy czasu upływającego wolno, ocknęła się we mnie świadomość, że mam w ręku instrument, który może mnie unieść ponad klęskę"73. Słowo, wolne słowo.

JT: Proszę Pani, a kiedy przenieśliście się Państwo koło Steinbecka ${ }^{74}$ do Sag Harbor? Jakie były dzieje wtedy?

\footnotetext{
${ }^{71}$ Ang.: wiejski dworek; mała willa.

${ }^{72}$ Ang.: dosłownie - znalazca gwiazd; tu: zapewne rodzaj prostego teleskopu.

${ }^{3}$ Wierzyńska cytuje fragment rozdziału Chopin i wiersze z tomu Moja prywatna Ameryka (s. 33); jej opustki uzupełniono w nawiasie kwadratowym.

${ }^{74}$ John Steinbeck (1902-1968), pisarz i dziennikarz amerykański, laureat Nagrody Nobla w 1962 roku. W Mojej prywatnej Ameryce Wierzyński sportretował go w rozdziale Steinbeck pije kawę.
} 
HW: Tak, ale jeszcze przedtem Panu powiem o dalszych losach tej książki, bo to wszystko było dość ciekawe, mianowicie wydawcę dla Chopina znalazł właściwie Artur Rubinstein, który zaniósł trzy gotowe i przetłumaczone rozdziały książki Dickowi Simonowi, dyrektorowi wielkiej firmy Simon \& Schuster. Książka została przyjęta i wyszła na rocznicę śmierci Chopina w 49 roku. Razem z książką skończył się właśnie Stockbridge, nie mieliśmy po co tam siedzieć. Zresztą najnowszy projekt literacki Kazimierza kierował nas w inne strony Ameryki. Projekt, z którego nic zresztą nie wyszło. Była to powieść o polskich osadnikach w Ameryce ${ }^{75}$, o czym nikt jeszcze nie pisał. Najlepszym terenem do obserwacji wydawała się Kazimierzowi Long Island, którą znaliśmy z jednej wizyty sprzed paru lat i z letniego pobytu w domu wynajętego od farmerów, państwa Kondratowiczów. Pojechaliśmy szukać miejsca zamieszkania do Sag Harbor i znaleźliśmy cudo: wielki, stary dom z końca XVIII wieku, ze wszystkimi nowoczesnymi ulepszeniami.

JT: I tam staliście się Państwo właśnie sąsiadami Steinbecka, autora Gron gniewu?

HW: Tak, Pan zresztą był w tym domu, prawda?

JT: Tak, ja byłem wtedy u Państwa, pamiętam. I to jest dom zupełnie jak z piastowskich czasów. Taki olbrzymi.

HW: Tak, z takim wielkim kominem.

JT: Z kominem... To był przepiękny dom, tak...

HW: ... i z belkami w suficie. Cudny dom. Tak więc, wtedy to był okres, kiedy znowu prawie nie widywaliśmy Polaków, chyba że ktoś do nas przyjechał z Nowego Jorku. Żyliśmy wśród samych Amerykanów, malarzy, aktorów, pisarzy. Koroną tego towarzystwa był John Steinbeck, który żył na ustroniu i obcował najchętniej z prostymi ludźmi, farmerami, robotnikami, a nie z inteligencją i artystami. O nim także pisze Kazimierz w swojej Prywatnej Ameryce. W 53 roku nastąpiła też zmiana w naszym składzie rodzinnym. Przyjechał do nas z Polski, a bezpośrednio ze Szwajcarii, bratanek Kazimierza, syn Hieronima, Grzegorz ${ }^{76}$, którego adoptowaliśmy i który od razu, nie tylko z imienia, stał się naszym dzieckiem. W Sag Harbor mieszkaliśmy dziesięć lat i stamtąd wyjechaliśmy do Paryża.

JT: A proszę Pani, z okresu paryskiego, jakie wiersze pisał tam Kazimierz i co się ukazało w druku?

${ }^{75}$ Maszynopis (trzydzieści pięć kart) tego niezrealizowanego utworu znajduje się w archiwum poety w Bibliotece Polskiej w Londynie (sygn. 1360/Rkps/V.6), opatrzony notatką Wierzyńskiej: „Próba powieści o polskich emigrantach w Ameryce pisana w Sag Harbor po 1949 nieprzeznaczona do druku" (wyróżnienie - H. W.).

${ }^{76}$ Grzegorz (Gregory) Wierzyński (ur. 1939); jego matką była aktorka Czesława z Zielińskich, zmarła w styczniu 1945 roku w Zakopanem; wiosną 1946 roku pod opieką stryjenki Jeanne (wdowy po przyrodnim bracie Kazimierza, Bronisławie) wyjechał do Szwajcarii, skąd Halina i Kazimierz sprowadzili go do USA, i w 1954 roku formalnie usynowili; późniejszy dziennikarz w amerykańskich magazynach, m.in. „The Time” i „Fortune” oraz w latach 1986-1988 dyrektor Radia Wolna Europa w Monachium. 
HW: Więc z okresu paryskiego była Tkanka ziemi i Kufer na plecach ${ }^{77}$. Są tam wiersze o Paryżu, Paryż $1959^{78}$ i jego świeże wrażenia. Z Paryża, czy to było wtedy...?, myśmy wyjechali do... tak, wtedy wyjechaliśmy do Barcelony. Wrażenia z Barcelony są w Cygańskim wozem ${ }^{79}$, w tym zbiorze opowiadań. Z Paryża wróciliśmy do Ameryki i najpierw mieszkaliśmy w Cambridge, w bardzo pięknym, wspaniałym domu (mieliśmy zawsze szczęście do dobrych domów) córki poety hiszpańskiego Guilléna ${ }^{80}$. Potem do końca października 64 roku mieszkaliśmy w Elmhurst pod Nowym Jorkiem. Z tego okresu też są wiersze Wyspy szcześliwe w tomie Kufer na plecach. W 64 roku przyjaciele nowojorscy z Haliną Rodzińską na czele urządzili wieczór Kazimierza, siedemdziesięciolecie jego urodzin i pięćdziesięciolecie pracy pisarskiej, w hotelu Barbizon Plaza ${ }^{81}$.

JT: Po tym okresie nastąpił, zdaje się, wyjazd Państwa do Londynu, tak? Czy jeszcze zatrzymaliście się Państwo w Ameryce w tym czasie?

HW: Tak, mieszkaliśmy w Cambridge, w Elmhurst, potem dostaliśmy mieszkanie w Manhattanie, takie upragnione, ale mieszkaliśmy tam tylko sześć tygodni ${ }^{82}$.

JT: To niewiele.

W Londynie poza tym to były dla nas nowe wrażenia, poczuliśmy się naprawdę na emigracji

HW: Nie, niewiele. I znowu wyjechaliśmy do Europy, przez Paryż do Rzymu ${ }^{83}$. W naszym rzymskim okresie zrobiliśmy cudowną wycieczkę do Grecji ${ }^{84}$, z której też są wiersze, wydane w zbiorze Sen mara ${ }^{85}$, opublikowanym po śmierci Kazimierza, Aleja w gtębi czasu, Kwiat pomarańczy, Epitafium dla filozofa, Adwokat, dla mnie bardzo tajemniczy wiersz, i Podwójne dno.

JT: I wtedy Państwo wyjechali już do Londynu, tak?

HW: Więc z Londynem to było tak: myśmy, mieszkając w Rzymie, wyjeżdżali na lato do Londynu z powodu upałów ${ }^{86}$. Londyn w lecie jest uroczy. Kto tego nie zauważył, to naprawdę nie miał oczu, bo jest słoneczny i chłodny, i pełen wdzięku. W Londynie poza tym to były dla nas nowe wrażenia, poczuliśmy się naprawdę na emigracji. Mieliśmy prezydenta, ministrów, wodza naczelnego i chociaż i w New Yorku, i w Rzymie mieliśmy świadomość ich istnienia, to tutaj spotykaliśmy ich w tych samych kołach towarzyskich. Poza tym emigracja w Londynie była (jak by to powiedzieć...?) samowystarczalna.

\footnotetext{
77 Tomy wyszły w Paryżu kolejno w 1960 i 1964 roku.

${ }^{78}$ Chodzi o cykl wierszy zatytułowany Paryż, wrzesień, 1959 z tomu Tkanka ziemi.

${ }^{79}$ Wierzyńscy odbyli podróż do Barcelony w czerwcu 1961 roku; chodzi o tom esejów Cygańskim wozem. Miasta, ludzie, książki (Londyn 1966).

${ }^{80}$ Jorge Guillén (1893-1984); w latach 1938-1977 przebywał na emigracji w Kanadzie, okresowo wykładał na Harvardzie w Cambridge. Wierzyńscy mieszkali w Cambridge od października 1961 do września 1962 roku.

${ }^{81}$ Wieczór odbył się 17 października 1964 roku; szczegółowy opis zob. B. Dorosz, Nowojorski pasjans, Warszawa 2013, s. 409_ -419 .

${ }^{82}$ Nowojorski adres Wierzyńskich na przełomie listopada i grudnia 1964 roku to Madison Avenue 1361

${ }^{83}$ W grudniu 1964 roku Wierzyńscy wyjechali z Nowego Jorku do Paryża, w styczniu 1965 roku dotarli do Rzymu, później odbyli wycieczkę po Włoszech (Arezzo, Perugia, Asyż, Florencja).

${ }^{84}$ Wycieczka do Grecji trwała od 18 kwietnia do 3 maja 1967 roku, podczas drugiego pobytu Wierzyńskich w Rzymie, od października 1966 do czerwca 1967 roku.

${ }^{85}$ Wyd. Paryż 1969

${ }^{86}$ Wierzyńscy przebywali w Londynie od lipca do października 1965 roku, później od lipca do września 1966 roku, zaś w czerwcu 1967 roku zamieszkali tam na stałe.
} 
JT: To była taka mała Polska, prawda?

HW: Mała Polska! Od pozycji intelektualnych i artystycznych w każdej dziedzinie usług był jakiś Polak. Był polski teatr i polska elegancka restauracja, polski budowniczy, polski dentysta, polski zegarmistrz. Poza tym byli znajomi i przyjaciele jeszcze z Warszawy: Grydzewski, Borman, Sakowscy, Benedyktowie ${ }^{87}$, i znowu żadnych Anglików. W 67 roku przyjechaliśmy do Londynu jak zwykle na wakacje i tym razem postanowiliśmy zostać na zimę. Znowu z niczego zaczęłam budować dom. No, to już moje stałe zajęcie. Wynajęliśmy mieszkanie ${ }^{88}$ bez mebli i trzeba było ten dom zaopatrzeć we wszystko.

JT: Zdaje się, od czasów początku emigracji Pani tylko urządzała nowy dom.

HW: Ja ciągle urządzałam.

JT: Później Pani wyjeżdżała, znowu nowy dom...

HW: ...ciągle urządzałam domy i ciągle pakowałam walizki. Podróżnicze życie. Kazimierz pracował wtedy dla Wolnej Europy, chciał się bardzo od tej pracy uwolnić. Nie miał sił. To było pełne zajęcie, cały tydzień... Przez ten tydzień musiał wymyślić temat, musiał dodać do tego jakąś dokumentację, musiał go opracować i napisać, i... już się zaczynał nowy tydzień i nowa taka sama praca. Chciał się od tego wykręcić, ale dyrektor Nowak znowu chciał zatrzymać jego nazwisko w programach radia i żeby znaleźć jakiś kompromis, zaproponował mu czytanie wierszy. Kazimierz nie miał na to wielkiej ochoty, ale w końcu zgodził się i dodawał do wierszy komentarze, które stworzyły rodzaj pamiętnika wierszy. Napisał dziewięćdziesiąt cztery takie audycje ${ }^{89}$. Potem dyrektor Nowak uwolnił go od tej pracy. Kazimierz pisał wiersze w Londynie. Weszły one do ostatniego zbioru Sen mara, wydanego przez „Kulturę” pośmiertnie.

Teraz, kiedy opowiedziałam prawie historię naszego życia, widzę, jakie ono było bogate i rozmaite i, dzięki cudownemu usposobieniu Kazimierza, pogodne i szczęśliwe. Na pewno nie opowiedziałam wszystkiego i nie wszystko na pewno dokładnie. Żeby pomóc mojej zawodnej pamięci, zrobiłam w Londynie dwie prace. Jedna to kalendarz życia Kazimierza, gdzie są wszystkie możliwe daty i szczegóły, a druga to bibliografia wierszy, z dokładną metryką każdego wiersza: wszystkie daty pierwodruków, pisma i druków w zbiorach. Obie rzeczy są złożone w Bibliotece Polskiej w Londynie.

JT: Bardzo Pani serdecznie dziękujemy za bardzo ciekawe uwagi i szczegóły z życia wielkiego poety, jednego z największych na emigracji, jakim był Kazimierz.

HW: Ja dziękuję za cierpliwość.

${ }^{87}$ Mieczysław Grydzewski (1894-1970), redaktor i wydawca tygodnika „Wiadomości”. Antoni Borman (1897-1968), współwydawca i administrator „Wiadomości”. Juliusz Sakowski (1904-1977), dyplomata, eseista, wydawca, i jego żona Stefania z Fruhlingów $1^{\circ}$ voto Zagórska (zm. 1984). Stefan Benedykt (1896-1987), legionista, major Wojska Polskiego, dziennikarz, prawnik; w czasie wojny walczył w AK, po aresztowaniu osadzony w obozie koncentracyjnym w Mauthausen; na emigracji m.in. długoletni prezes Związku Kacetowców i sekretarz generalny Instytutu J. Piłsudskiego w Londynie; brak informacji biograficznych na temat żony.

${ }^{88}$ W Londynie od 15 października 1967 roku Wierzyńscy mieszkali przy Queen's Gate Terrace.

${ }^{89}$ Audycje te przygotowywał Wierzyński od 1962 roku; wyszły drukiem jako Pamiętnik poety (oprac. P. Kądziela, Warszawa 1991); nieliczne teksty niewłączone do tomu zachowały się w archiwum poety w Bibliotece Polskiej w Londynie. 
Key Words: Kazimierz Wierzyński, Halina Wierzyńska, Jerzy Tepa, Second World War, emigration, poetry, interview, sound recording, editing, "translation" of a recording into printed text

Abstract: The text is the first printing of the interview with Halina Wierzyńska, the widow after Kazimierz Wierzyński, recorded in New York in the late 1970s for the Polish Institute of Arts and Sciences of America and conducted by Jerzy Tepa. The subject of their conversation were the whereabouts of the Wierzyńskis' departure from Warsaw in September 1939 after the outbreak of war, the stages of their wandering (through Romania, France, Brazil to the United States), and the experiences related to settling in a foreign country; in this context, Wierzyńska tells about the poet's works written at that time, which were a testimony of both his patriotic and immigration experiences. The account also indirectly hints at the enormous effort of daily existence, resulting from the necessity of constant travelling due to, among other factors, the need to search for means of providing for oneself.

The introduction to the interview indicates the basic problems related to preparing a printed version of a text whose original form was a sound recording. The publication is at the same time an invitation made to the editors' circles to engage in a discussion on the theoretical assumptions and methodological tips concerning the "translation" of a recording into printed text. 